NBER WORKING PAPER SERIES

\title{
LEVELING UP: EARLY RESULTS FROM A RANDOMIZED EVALUATION OF POST-SECONDARY AID
}

\author{
Joshua Angrist \\ David Autor \\ Sally Hudson \\ Amanda Pallais \\ Working Paper 20800 \\ http://www.nber.org/papers/w20800
NATIONAL BUREAU OF ECONOMIC RESEARCH
1050 Massachusetts Avenue \\ Cambridge, MA 02138 \\ December 2014, Revised March 2017
}

We are grateful to Enrico Cantoni, Sydnee Caldwell, Olivia Kim, Brendan Malone, Kemi Oyewole, and Karen Scott for superb research assistance, and to the staff of the Susan Thompson Buffett Foundation for their expert assistance in implementing the evaluation described here. We also thank the Provost's Office at the University of Nebraska, the Nebraska State College System, and Nebraska's community colleges for their support for this effort and for sharing their data. We thank Raj Chetty, Amy Finkelstein, Nathan Hendren, Lisa Kahn, Lawrence Katz, Danielle Li and seminar participants at NBER Summer Institute, IIES, Harvard, MIT and Yale for their many helpful comments and suggestions. We acknowledge financial support from the Susan Thompson Buffett Foundation and the MIT SEII seed fund. The views expressed here are those of the authors alone and do not necessarily reflect those of the institutions or funders involved with this work, nor those of the National Bureau of Economic Research. This RCT was registered with the American Economic Association under trial number AEARCTR-0000125.

NBER working papers are circulated for discussion and comment purposes. They have not been peer-reviewed or been subject to the review by the NBER Board of Directors that accompanies official NBER publications.

(C) 2014 by Joshua Angrist, David Autor, Sally Hudson, and Amanda Pallais. All rights reserved. Short sections of text, not to exceed two paragraphs, may be quoted without explicit permission provided that full credit, including $\odot$ notice, is given to the source. 
Leveling Up: Early Results from a Randomized Evaluation of Post-Secondary Aid

Joshua Angrist, David Autor, Sally Hudson, and Amanda Pallais

NBER Working Paper No. 20800

December 2014, Revised March 2017

JEL No. H52,I21,I22,I23,I28,J24

\begin{abstract}
$\underline{\text { ABSTRACT }}$
Does financial aid increase college attendance and completion? Selection bias and the high implicit tax rates imposed by overlapping aid programs make this question difficult to answer. This paper reports initial findings from a randomized evaluation of a large privately-funded scholarship program for applicants to Nebraska's public colleges and universities. Our research design answers the challenges of aid evaluation with random assignment of aid offers and a strong first stage for aid received: randomly assigned aid offers increased aid received markedly. This in turn appears to have boosted enrollment and persistence, while also shifting many applicants from two- to four-year schools. Awards offered to nonwhite applicants, to those with relatively low academic achievement, and to applicants who targeted less-selective four-year programs (as measured by admissions rates) generated the largest gains in enrollment and persistence, while effects were much smaller for applicants predicted to have stronger postsecondary outcomes in the absence of treatment. Thus, awards enabled groups with historicallylow college attendance to 'level up,' largely equalizing enrollment and persistence rates with traditionally college-bound peers, particularly at four-year programs. Awards offered to prospective community college students had little effect on college enrollment or the type of college attended.
\end{abstract}

Joshua Angrist

Department of Economics, E52-436

MIT

77 Massachusetts Avenue

Cambridge, MA 02139

and IZA

and also NBER

angrist@mit.edu

David Autor

Department of Economics, E52-438

MIT

77 Massachusetts Avenue

Cambridge, MA 02139

and NBER

dautor@mit.edu
Sally Hudson

Garrett Hall L032

235 McCormick Road

Charlottesville, VA 22904-4893

USA

sally.hudson@virginia.edu

Amanda Pallais

Department of Economics

Harvard University

Littauer Center

Cambridge, MA 02138

and NBER

apallais@fas.harvard.edu 


\section{Introduction}

Every year, U.S. government agencies and many private groups distribute billions of dollars in college financial aid. The federal government spends about $\$ 32$ billion annually on Pell Grants alone (Congressional Budget Office 2013). A large body of research attempts to determine if this aid affects college choice and attendance (see, for example, Abraham and Clark (2006); Avery et al. (2006); Goodman (2008); Kane (2007); Bound and Turner (2002); Dynarski (2000); Cornwell, Mustard and Sridhar (2006)). ${ }^{1}$ As Deming and Dynarski (2009) explain, however, selection bias and the complicated nature of college aid programs make the relationship between financial aid and post-secondary outcomes hard to interpret. Perhaps not surprisingly in view of these challenges, empirical assessments have produced a wide range of impact estimates, many of which appear sensitive to the underlying assumptions used to identify causal effects.

This paper reports initial results from a randomized evaluation of one of the largest private aid programs in the country. For decades, the Susan Thompson Buffett Foundation (STBF) has offered grants to Nebraska high school seniors who express interest in attending the state's public colleges and universities. The largest STBF awards are worth more than $\$ 60,000$, covering tuition and fees for up to five years of study at any Nebraska public college. Interested students apply for STBF aid as high school seniors. Awardees are selected on the basis of financial need, high school GPA, and a review of personal statements and reference letters. STBF aid recipients, called Buffett Scholars, can use their awards to cover costs at any University of Nebraska campus (known collectively as NU), any of the six Nebraska community colleges, or at a set of three four-year state colleges outside the NU system. Buffett Scholars who attend NU also participate in Learning Communities (LCs), a Foundation-supported academic services intervention similar to other Learning Communities programs around the country. ${ }^{2}$ The Buffett program supports more than 3,000 students each year, with annual spending running more than $\$ 25$ million.

In an effort to gauge the effectiveness of grant aid and Learning Community access, we implemented a randomized evaluation of the STBF program, awarding more than 2,000 scholarships via random assignment. The results reported here include applicants applying for college entry in the Fall of 2012 and in the Fall of 2013, covering a follow-up window that extends into sophomore year

\footnotetext{
${ }^{1}$ Leslie and Brinkman (1987) and Deming and Dynarski (2009) survey this literature.

${ }^{2}$ See Weiss et al. $(2015 b)$ for a review of research on LC impacts.
} 
for the 2012 cohort.

Our first important finding is that STBF scholarship offers substantially increased the amount of financial aid Buffett Scholars received. This result is far from automatic: as a rule, federal and institutional grants fall in response to increased outside financial support, implicitly taxing away the added funds. In this case, however, agreements between STBF and Nebraska's public colleges minimize offsetting reductions in institutional aid. As a result, STBF award offers increased students' grant aid by about $\$ 6,200$ on average in the first year and $\$ 6,400$ in the second. This represents a net increase of 91 cents in grant aid for every STBF dollar awarded, with offsetting reductions in government loans and Federal Work Study aid of 29 cents and six cents per dollar awarded, respectively. ${ }^{3}$

STBF support also changed students' enrollment behavior. Aid offers increased the probability that a student enrolled in any college in the first year by only two percentage points, but there was little room for improvement on this margin since 97 percent of control students enrolled in college even without STBF support. At the same time, STBF support substantially altered students' college choices: the fraction of applicants matriculating at four-year colleges rose by almost eight points.

Gains in sophomore enrollment were more substantial: aid offers increased overall sophomore enrollment by 7.2 points, with four-year enrollment gains of 14 points. Persistence increased most among groups that typically have low persistence rates: we find a remarkable 20-plus point gain in four-year enrollment for nonwhite applicants and for those with ACT scores below the state median. Persistence effects were also larger for male applicants and students with low high school GPAs. On balance, STBF scholarships substantially equalized enrollment and persistence rates across groups, enabling students with low expected persistence to 'level up' with their traditionally college-bound peers. In contrast, applicants who targeted community colleges were largely unaffected by STBF awards.

To distinguish the effects of STBF's financial aid from those of LC services, our second experimental cohort included a group that was offered aid without access to LCs. This aid-only treatment, known to applicants as the College Opportunity Scholarship (COS), offered financial support to NU

\footnotetext{
${ }^{3}$ Reported offset amounts are from the first year of enrollment. Offsets of grants and government loans were slightly smaller in the second year, while the offset of work-study aid was similar.
} 
applicants in the same amounts and under the same conditions as full STBF awards, but without offering seats in the STBF LC programs operating on NU campuses. Initial findings from the aidonly treatment show effects similar to those generated by full award offers, with some evidence the LC treatment induced applicants to enroll and persist at more selective colleges than would have otherwise been the case. Because the COS cohort enrolled in 2013, comparisons between COS and traditional full STBF awards are still provisional.

Our study contributes to the burgeoning literature on the causal effects of college financial aid on aid recipients. Like the STBF program, much of the new wave of government aid for college is merit- as well as need-based. Dynarski (2004) reviews research on state merit aid programs modeled on Georgia's HOPE Scholarship. Most of this work exploits state-by-cohort variation in access to government aid. Dynarski concludes that the HOPE program had large and significant effects on college attendance. She also reports positive (though smaller) effects for similar merit aid programs across the South. The effects of these programs, however, vary widely across racial and socioeconomic groups, with three out of the four programs studied showing larger gains among minorities and the HOPE program itself seeming to generate smaller gains for minorities.

In contrast with the differences-in-differences style evaluations that feature in many recent impact evaluations of aid, Marx and Turner (2015) use discontinuities in the Pell Grant formula to evaluate aid effects on City University of New York (CUNY) students. Regression discontinuity estimates suggest Pell aid reduces CUNY students' borrowing without affecting their schooling. Like most regression discontinuity designs, these results are most relevant for students with running variable values near kinks and cutoffs. It's also worth noting that most CUNY students attend campuses that are more selective than the Nebraska schools targeted by our sample.

Our work is also closely related to a recent randomized evaluation of need-based grant aid at Wisconsin's public colleges by Goldrick-Rab et al. (2016). The Wisconsin Scholars Grant (WSG) offered an additional $\$ 3,500$ to Pell-eligible Wisconsin residents who were already enrolled as fulltime freshmen at four-year public institutions. Results from the Wisconsin evaluation suggest WSGs had modest effects on sophomore enrollment, with no evidence of effects beyond the second year. Our intervention similarly uses a randomized research design, but STBF awards are more than twice as large as the Wisconsin grant. In addition, our intervention targets high school students who have yet to make their initial enrollment decisions. Our design therefore reveals aid effects on 
whether and where students go to college.

Finally, a large literature examines the value of post-secondary support services. A recent randomized evaluation of Learning Communities interventions at Kingsborough Community College in New York shows only modest impacts (Bloom and Sommo 2005), though Weiss et al. (2015a) find stronger effects. Two randomized evaluations of traditional support services for Canadian college students show some benefits from services combined with merit aid, though only for women (Angrist, Lang and Oreopoulos 2009; Angrist, Oreopoulos and Williams 2014). A recent randomized evaluation of mentoring and coaching (Bettinger and Baker 2014) suggests this sort of intervention can be highly cost-effective.

The next section describes the STBF program and our experimental design. Section 3 discusses the scholarships' effects on students' financial aid packages. Section 4 reports reduced-form estimates of the effect of aid offers on college matriculation and persistence, including effects in important subgroups. Section 5 combines the reduced-form and first-stage analysis to estimate and compare cost effectiveness across target institutions. In a calculation that builds on the pioneering evaluation of federal BEOG grants in Fuller, Manski and Wise (1983), we also show how the experimental estimates can be used to distinguish program spending that changes behavior from infra-marginal spending that amounts to a pure transfer. Provisional results from the aid-only arm of the experiment are discussed in Section 6. Finally, Section 7 summarizes the findings and briefly discusses our work in progress.

\section{Background}

\subsection{The STBF Scholarship Program}

The Susan Thompson Buffett Foundation has offered financial aid to Nebraska college students since 1965. The Foundation is the largest private grant provider in the state and among the largest in the country, supporting more than 3,000 students each year. STBF aid can be applied toward expenses at any public undergraduate institution in Nebraska, including two- and four-year colleges.

As with federal Pell Grants, STBF award criteria consider financial need; like many state aid programs, STBF awards are also partly based on merit. The STBF program is distinct from government programs, however, in that the STBF merit assessment considers both quantitative and 
qualitative inputs, including financial need, high school transcripts, essays, and letters of recommendation. STBF awards are also unusually generous and available to some students who are ineligible for federal Pell grants. The STBF-eligible applicant pool consists of Nebraska-resident high school seniors or graduates of in-state high schools who have not yet been to college. STBF gauges financial need using the Expected Family Contribution (EFC) determined by the government's Free Application for Federal Student Aid (FAFSA). ${ }^{4}$ EFC cutoffs for Buffett Scholarships were $\$ 15,000$ in 2012 and $\$ 10,000$ in 2013, while Pell cutoffs were much lower $(\$ 5,081$ in 2013). STBF also considers college readiness, requiring a minimum 2.5 high school GPA. The scholarship application asks students to indicate which schools they plan to attend should they receive awards. Although this is a non-binding declaration, in practice, most applicants attend the school they identify as their target. Applicants' target schools also figure importantly in the review process: after applications are scored, students are ranked against those who have indicated the same target.

STBF award amounts vary by campus but are calibrated to match the cost of tuition and fees for a full-time student plus a $\$ 500$ allotment for books. For example, 2013 awards provided up to $\$ 8,500$ per academic year for full-time students at the University of Nebraska-Lincoln campus, where full-time resident tuition and fees ran to $\$ 8,060$. STBF provides an additional semester's worth of funding for summer enrollment, so that the maximum 2013 award was $\$ 12,750 .{ }^{5}$ The maximum annual award for attending a two-year program was $\$ 5,400$ in 2013 . Though tuition prices determine the value of STBF awards, the award money can be used to cover any of the federallydefined components of cost-of-attendance (COA), including room, board, books, and supplies. ${ }^{6}$ This flexibility further boosts the scholarship's value relative to many aid programs, which often cover only tuition and fees. Because most Buffett Scholars qualify for public need-based aid like Pell Grants, STBF awards often cover the remaining balance of students' COA, eliminating the need

\footnotetext{
${ }^{4}$ Home-schooled students are eligible for Buffett aid, as are GED recipients who earned their credentials in Nebraska. Undocumented immigrants are also eligible, but legal residents of other U.S. states are not. Undocumented immigrants can apply for Buffett aid without completing a FAFSA.

${ }^{5}$ As far as we know, the only state program that approaches this level of generosity is California's merit-based Cal Grant A, studied in Kane (2003). See Table 1 of Deming and Dynarski (2009) for a review of financial aid programs. In comparison, the maximum Pell Grant was $\$ 5,550$ in $2012-13$, while the average Pell award was $\$ 3,650$ (College Board 2014).

${ }^{6}$ Post-secondary schools that receive federal aid report COA figures to the federal government. COA includes tuition and fees, room and board, books and supplies, and personal costs such as transportation. STBF transfers scholarship funds directly to schools, who then apply the funds to awardees' college bills. Since COA components like off-campus housing and supplies do not appear on college bills, colleges distribute unused STBF award money by writing checks to students with credit balances. The total value of aid received cannot exceed COA, however. Awards are prorated for less than full-time attendance.
} 
for loans or out-of-pocket contributions to college costs. Buffett awards are renewable for up to five years provided students meet minimal academic standing requirements, though no more than three years of funding can be paid toward two-year college expenses (Students enrolled for fewer than nine credits per semester or with a cumulative GPA below 2.0 risk losing their scholarships).

Buffett Scholars who attend one of NU's three campuses - Lincoln (UNL), Omaha (UNO), or Kearney (UNK) - are required to participate in the Thompson Scholars Learning Community (LC) programs during their first and second years. These programs are designed to promote academic success and social engagement. While the LC programs differ somewhat by campus, they all include specialized classes with other Buffett scholars, academic and social activities, peer mentoring, and academic advising services from LC faculty and staff. In two of the LC programs (UNK and UNL), the majority of scholarship recipients live together in a residence hall. Buffett Scholars who fail to participate in LC activities risk losing their scholarships.

\subsection{Research Design}

For the purposes of this research, STBF applicants for 2012 and 2013 matriculation were divided into three groups based on reviewer ranks. The most highly-ranked applicants (301 out of 1,430 eligible applicants in 2012 and 356 out of 2,267 in 2013) were guaranteed awards, while the lowestscoring applicants (127 in 2012 and 273 in 2013) were removed from consideration. The rest were subject to random assignment, with award rates determined by STBF preferences for award counts at the target schools in each cohort. (The estimated program impacts discussed below control for a full set of target school by year of application dummies - what we call strata dummies - to reflect differential award rates across strata). The 2012 randomization group included 1,003 applicants, 504 of whom were offered aid. The 2013 randomization group included 1,638 applicants, 697 of whom were offered aid. Appendix Table A1 reports further information on sample size and target colleges.

Among the 2013 randomized applicants who targeted NU, there were two types of aid offers, as noted above: a full scholarship with mandatory LC participation for those matriculating at NU and an equivalent aid award with no LC requirement. Of the 697 random awards offered in 2013, 210 were aid-only College Opportunity Scholarships (COS). We focus here on the effect of full awards, reporting results primarily from a 2013 analysis sample that includes the 1,428 experimental 
applicants not offered the COS. Section 6 reports briefly on the ongoing comparison of COS and full awards.

\subsection{Data and Descriptive Statistics}

Data for this project come primarily from the STBF scholarship application, the administrative records of Nebraska's public colleges, and the National Student Clearinghouse (NSC). The application provides a rich set of baseline characteristics, including high school transcripts, ACT scores, and detailed demographic and financial information from federal Student Aid Reports. The application did not ask students to report their race; we obtained race data from state driver's license records.

More than 90 percent of applicants who enrolled in college attended a Nebraska public institution. These colleges and universities provided information on their students' enrollment, aid packages, and academic outcomes. To capture enrollment at private and out-of-state colleges, we supplemented school-provided data with information from the NSC, which captures 92 percent of enrollment nationwide (Dynarski, Hemelt and Hyman 2015). NSC records report institution attended and enrollment status (full-time, half-time, etc.) We provide additional information about data sources and data processing in the appendix.

STBF applicants in 2012 and 2013 were, on average, from substantially poorer households than the general population of Nebraska high school seniors. This can be seen in the first two columns of Table 1, which compare descriptive statistics for scholarship applicants and high school students statewide. STBF applicants were also disproportionately female and less likely to have collegeeducated mothers. ACT scores among applicants were similar to those of other Nebraska ACT test-takers, though applicants were more likely than other Nebraska seniors to have taken the ACT.

Column 3 of Table 1 reveals that STBF's top-ranked applicants, those who received awards without being subject to random assignment, had academic credentials similar to those in the randomization group. The most important difference between the automatically-funded and randomized groups was socioeconomic status: students who received STBF awards without random assignment had lower family incomes and less educated mothers. This group also contained a higher proportion of Hispanic applicants. At the other end of the applicant pool, those disqualified before random assignment had lower high school grades and ACT scores than those in the randomization 
group.

Random assignment successfully balanced the characteristics of those in the randomization group who were and were not offered aid. This is documented in column 6 of Table 1, which reports strataadjusted differences in treatment and control characteristics, along with the associated standard errors. Appendix Table A2 reports balance estimates separately for the two randomization cohorts, while Appendix Table A3 reports balance estimates within strata. Treatment and control students in the randomization group had family incomes around $\$ 50,000$ per year and Expected Family Contributions of just over $\$ 3,000$. Roughly two-thirds of those randomized are white and about 60 percent are female.

\section{How Awards Changed Aid Packages}

We begin by describing the effect of STBF awards on Buffett Scholars' financial aid packages. This analysis is necessarily limited to the sample of students who attended Nebraska public colleges since our administrative aid data come from these colleges. Because STBF awards affect the likelihood of being part of this sample, the analysis here may be compromised by selection bias. In practice, however, the effect of STBF awards on the likelihood of having detailed aid data is small—awards change the probability of attending a Nebraska public college by no more than six percentage points - and the effects of STBF award packages on aid composition are large. It therefore seems likely that the picture painted here, though in principle more descriptive than causal, still provides a useful gauge of the value of aid for recipients.

As a benchmark, the first column of Table 2 describes the first-year financial aid packages of control group students who attended Nebraska public colleges. Aid amounts averaged over $\$ 11,500$, of which roughly $\$ 7,250$ is grant aid, with the remainder divided between government loans (about $\$ 3,500$ ) and work study (about $\$ 800$ ). Our aid figures omit private loans, a category for which we have limited data; however, subsidized public loans are the primary source of borrowed funds for this low-income population.

Estimates of the effects of scholarship offers on aid packages come from regression models of the form: 


$$
A_{i}=\beta S_{i}+\sum_{s, c} \delta_{s c} r_{i s c}+\gamma^{\prime} X_{i}+\varepsilon_{i}
$$

where $A_{i}$ is the dollar amount of aid student $i$ received and $S_{i}$ is an indicator for whether student $i$ was (randomly) offered an STBF scholarship. The dummies $r_{i s c}$ indicate whether applicant $i$ from cohort $c$ listed school $s$ as her intended college. These cohort-specific strata dummies account for differential award rates by target college and application year. The covariate vector, $X_{i}$, includes family income, EFC, high school GPA, and ACT composite score. To the extent that selection into Nebraska public colleges varies with these traits, $X_{i}$ mitigates the associated bias. Finally, $\varepsilon_{i}$ is a person-specific error term. To estimate the effect of a dollar of STBF aid on dollars of other aid received, we replace $S_{i}$ in equation (1) with the dollar amount of each STBF scholarship.

Scholarship winners received an average of $\$ 6,924$ in STBF grant aid in their first year (Because a few students turned down STBF scholarships in favor of other named awards, this is an intentto-treat contrast between treatment and control subjects.) STBF awards increased total grant aid by $\$ 6,225$, from a base of $\$ 7,251$ in the control group. The less than one-for-one aid pass-through reflects a $\$ 698$ decline in institutional awards and private grants and a (statistically insignificant) decrease of one dollar in federal grants. For some students, the reduction in institutional aid reflects the COA cap on total aid disbursed, rather than a discretionary reduction on the part of institutional aid officers.

Increased grant aid substantially reduced students' reliance on student loans and use of work study programs. Column 2 of Table 2 shows that aid offers reduced government loans by $\$ 2,220$ and Federal Work Study aid by $\$ 486$ (both around 60 percent of the corresponding control group means). Total aid - the sum of grants, federal loans, and work study-averaged $\$ 11,608$ in the control group and was just over $\$ 3,300$ higher in the treatment group. The estimates in column 4 of Table 2 show that each dollar of STBF grant aid increased students' total grant aid by $\$ 0.91$, while reducing loans by $\$ 0.29$ and reducing work study by $\$ 0.06$, for a net gain of $\$ 0.53$ per dollar awarded.

These results capture two countervailing effects of scholarship offers on the amount of aid received. At any given college, scholarship money crowds out aid from other sources, reducing award effects on total aid received. But awards also change students' college choices. In particular, as we 
explore in detail below, STBF awards caused many applicants who would have otherwise gone to two-year schools to attend four-year schools at a higher cost. This shift is captured in the first row of Table 2, which shows Buffett Awards increasing students' cost of attendance by $\$ 0.24$ per dollar of aid received. Though four-year colleges cost more, they also provide more grant aid: the average control group student attending a four-year college received $\$ 7,600$ in grant aid, $\$ 4,000$ more than the average control student attending a two-year college. Scholarship money therefore "crowds in" aid by moving students to more expensive campuses that offer more financial aid.

To disentangle the crowd-out and crowd-in effects, columns 3 and 5 of Table 2 (labeled "campus adjusted") report estimates of a version of equation (1) that includes campus controls, that is, a set of variables that count the number of full-time equivalent terms students attended at each Nebraska public college in the aid year. These campus-adjusted regressions isolate the extent to which, at a given college, STBF aid crowds out other forms of aid. The results in column 5 show that, at a given college, students lost $\$ 0.22$ in total grants for each scholarship dollar awarded, an effect that's more than twice as large as the loss estimated without campus controls. Of course, these results should be interpreted cautiously, since campus choice is an outcome affected by STBF awards. Results from models with campus controls therefore combine causal effects on aid packages for those whose choices are unchanged by STBF awards with compositional effects that result from treatment-induced changes in college attended. These compositional effects, a form of selection bias generated by conditioning on outcomes, arise if, conditional on observed characteristics like EFC, treatment and control students attending the same college would be offered different financial aid packages in the absence of treatment. Because institutional awards are in large part a mechanical function of student traits like EFC, the extent of selection bias in this case is likely to be modest.

Buffett awards changed financial aid packages even more substantially in year two than in year one, with smaller offsetting reductions in aid from other sources. These and other results for secondyear aid packages appear in Table 3, again for a sample of those enrolled in Nebraska public colleges. ${ }^{7}$ The net increase in total aid generated by a dollar of STBF money in year two was 73 cents, while the campus-adjusted increase was 41 cents. STBF awards also reduced loans and work study in year two. Appendix Table A4 extends the results in Tables 2 and 3 with an analysis of effects on

\footnotetext{
${ }^{7}$ Aid data in year two is necessarily missing for those who leave college. Year two aid data is missing for about ten percent of the year one control sample and for about five percent of the year one treatment sample for which aid is available in year one.
} 
more detailed aid categories.

\section{Effects on Enrollment and Persistence}

\subsection{College Enrollment}

The vast majority of STBF applicants attended college in the first year after application whether or not they won STBF awards. This is apparent in Table 4, which shows control means for enrollment outcomes and estimated effects of scholarship offers using data from the first year of potential enrollment. Although 97 percent of control students enrolled in college, STBF awards increased this rate by a statistically significant two percentage points. This estimate and others in Table 4 come from a regression model similar to that described by equation (1), where, instead of aid awarded, the dependent variables are enrollment outcomes. All students in the experimental group are included in these regressions regardless of whether they attended Nebraska public colleges. Covariates are included in an effort to increase precision.

Buffett awards increased four-year college attendance by 7.8 points above a control mean of 75 percent. Two-year attendance, in contrast, fell by about six points. The increase in four-year attendance therefore reflects a shift from two to four-year schools. This institutional upgrading is likely a consequence of the tuition subsidy implicit in the STBF award scheme: Buffett awards cover tuition at any Nebraska public college, and the four-year colleges cost twice as much.

STBF awards decreased the fraction of students attending out-of-state or private colleges from seven percent to about three. Importantly, however, and in contrast with findings for the Massachusetts's Adams Scholarship reported by Cohodes and Goodman (2014), the shift to Nebraska public schools was concomitant with a shift towards more selective institutions. Specifically, STBF awards increased the proportion of students attending selective colleges (colleges with admission rates below 75 percent) by nearly four points. The fraction of students attending moderatelyselective four-year colleges (with admissions rates between 75 and 90 percent) increased by a similar amount. 8 Most STBF applicants students who chose out-of-state colleges attended less selective colleges close to the Nebraska border; STBF aid pushed some of them to more selective NU cam-

\footnotetext{
${ }^{8}$ UNL's admission rate is below $75 \%$, while UNK and UNO both have admissions rates between $75 \%$ and $90 \%$. The remaining Nebraska public colleges have admissions rates above $90 \%$.
} 
puses.

Effects in target college strata capture differences across groups of applicants with more or less ambitious higher education plans. Those targeting relatively-selective UNL were almost certain to enroll in college, so STBF awards changed overall enrollment status little in this group. Even among these relatively ambitious students, however, the scholarship increased the fraction of students attending four-year colleges by 6.5 points and increased the fraction of students attending selective colleges by 12 points.

Overall enrollment effects were larger for applicants targeting UNO and UNK. In this group, STBF awards boosted post-secondary enrollment by 3.4 points and the proportion enrolling on a four-year campus by an impressive 13 points. STBF offers in the UNO/UNK strata also increased attendance in moderately-selective colleges by 15 points. This change is due in part to awardees' shift from two-year programs to their target colleges.

We see little evidence of scholarship-induced changes in first-year enrollment outcomes for applicants targeting state and community colleges. Estimated enrollment effects in both groups are small and none are significantly different from zero. Unlike students targeting NU campuses, few who targeted community colleges chose to attend four-year programs as a result of award receipt.

\subsection{College Persistence}

Many interventions produce short-lived gains, but STBF awards generated a large and growing impact on students' college enrollment. This can be seen in Table 5, which shows estimates analogous to those in Table 4 for the second year after scholarship application. STBF awards appear to have substantially reduced dropout rates between freshman and sophomore years. Enrollment among treated students decreased just four points, from 99 percent in the first year to 95 percent in the second. The dropout rate was twice as large among control students, whose enrollment rate fell from 97 percent in year one to 88 percent in year two. Thus, STBF awards increased year-two enrollment by more than seven points. The awards also led enrolled students to take more credits. By the end of year two, treated students had amassed an additional 0.37 semester equivalents of college enrollment, about twice the effect we would expect to see if enrolled treated students took the same number of credits as enrolled control students. ${ }^{9}$ Year-two effects on four-year college going

\footnotetext{
${ }^{9}$ The data appendix details the link between credit completion and semester equivalents.
} 
were even larger: STBF awards increased four-year enrollment by 14 points in year two, twice the effect in year one.

As with the first-year results, those for year two show important differences across target-school strata. The largest effects on four-year enrollment are for applicants who targeted UNO and UNK, the less selective of the three NU campuses. STBF awards boosted four-year enrollment for these applicants by a remarkable 24 points in year two, with the entire gain coming from enrollment in moderately-selective colleges (a group which includes these targets). Again, these estimates are about twice as large as the effects on first-year enrollment. Though STBF awards had no impact on initial enrollment in the state college strata, awards increased second-year enrollment in this group by 13 points. By the end of year two, treated students targeting state colleges had amassed about two-thirds of a semester more than the control group. Again, however, awards did little to alter enrollment outcomes in the group targeting community colleges.

Why do STBF award effects increase so markedly in year two? Table 6 sheds light on this question by reporting effects on the joint distribution of enrollment in the first two years of followup for the 2012 cohort. The first column and first row report marginal effects on enrollment in years one and two, respectively, while the remaining rows and columns report joint effects. Control means are reported in braces in each cell. The first cell in row 1 shows that 88 percent of control group students enrolled in post-secondary schooling in the second year of the experiment and that award offers raised this probability by 7.2 points. The estimate in row 2 , column 2 shows that the scholarship offer raised the joint probability of any post-secondary enrollment in both year one and year two by 7.6 percentage points. The cell in row 5 , column 2 reveals that second year enrollment is effectively zero conditional on non-enrollment in year one. Hence, the treatment-induced gains in year two enrollment seen in Table 5 are due almost entirely to retention of those who start college in year one.

Many control group students drop out of college, especially those enrolling initially in four-year programs. While 76 percent of control group students enrolled in four-year colleges in year one, just 63 percent enrolled in four-year colleges in both years. About 60 percent of four-year college dropouts were not enrolled anywhere in year two, while the remainder were enrolled in two-year colleges. Because STBF awards increased the number of students enrolling in four-year colleges in year one, we would have expected the number of students dropping out of four-year colleges in 
year two to increase unless awards also raised persistence rates. Row 3, columns 4 and 5 reveal, however, that the fraction of students who started at four-year colleges and dropped out is about half as large in the treatment group. This implies that the scholarship caused some students who were infra-marginal for four-year enrollment in year one to persist in four-year enrollment in year two.

Table 6 weighs against the view that those induced to attend four-year colleges are ill-prepared for more challenging courses and therefore at increased risk of dropping out, a version of the college mismatch hypothesis (see, for example, Arcidiacono, Aucejo and Hotz 2016). If STBF awards had induced students to enroll in four-year colleges for which they were ill-prepared, we might have seen an increase in the number of students initially enrolling in four-year colleges and subsequently transferring to two-year schools or dropping out of college entirely. As it turns out, however, the findings go the other way: the odds of starting a four year program and dropping out or transferring in year two decline in the treatment group, with the largest drop seen for the combination of a fouryear start and second-year non-enrollment (a 4.4 point decline).

\subsection{For Whom Does Aid Matter Most?}

Estimates of effects in demographic subgroups reveal important differences in program impacts. This is apparent in Figure 1, which plots year-two enrollment by race, gender, and treatment status. In this figure and those that follow, the treatment group mean was constructed by adding the control mean and treatment effect, estimated from a model that includes strata dummies and covariates as in equation (1). (Whiskers depict the 95 percent confidence interval for the treatment effect.) Nonwhites in the control group were much less likely to attend college in year two than were whites, with an especially large race gap in four-year enrollment (compare 55 percent for nonwhites with 71 percent for whites). Yet STBF awards nearly equalized these rates across races by generating especially large gains for nonwhite awardees. Figure 1 documents a similar, but less stark, pattern for male and female applicants. Among students who were not awarded scholarships, males were less likely to enroll in four-year colleges than females (60 percent versus 69 percent), a gap that disappears in the treatment group.

Figures 2 and 3 reveal similarly striking leveling-up patterns in effects estimated conditional on ACT scores and high school GPA, both strong predictors of enrollment and persistence. In 
these figures, the darker lines plot enrollment rates for treated applicants, and the lighter lines depict control group enrollment. ${ }^{10}$ Not surprisingly, control students with lower baseline academic achievement were much less likely to attend college in year two than their higher scoring peers. In particular, Figure 2 shows a 23 point gap in year-two enrollment between students in the highest and lowest GPA bins (95 percent versus 72 percent), while Figure 3 shows a 12 point enrollment gap between the highest and lowest ACT bins (91 percent versus 79 percent). STBF scholarships virtually closed these gaps: in the treatment group, the high-low gap in year-two enrollment by GPA is just two points (98 percent versus 96 percent), while the high-low gap by ACT score is just four points (99 percent versus 95 percent). ${ }^{11}$

The lower panels of Figures 2 and 3 show the same general pattern of subgroup effects for four-year college enrollment in year two, though here leveling-up is incomplete. The high-low gap in four-year enrollment by high school GPA is a whopping 57 points in the control group (28 percent versus 85 percent) as compared with 39 points in the treatment group (66 percent versus 95 percent), a one third reduction. Comparing four-year enrollment by ACT score, the high-low gap is 47 percent among controls (42 percent versus 89 percent), but only 29 percent in the treatment group (96 percent versus 67 percent), a reduction of more than 40 points. Thus, while award offers increase four-year college attendance at all levels of baseline achievement, students who are least prepared gain more.

Though award impacts vary by race, gender, and academic achievement, we see little evidence of differential impact by financial need. If anything, effects on four-year enrollment are somewhat larger at higher EFC levels, a result that can be seen in Figure 4. This pattern may reflect the interaction between STBF aid and other need-based financial aid systems. Students with EFCs above about $\$ 5,000$ were ineligible for federal Pell grants in 2012 and 2013. Consequently, among applicants with EFCs low enough to qualify for Buffett aid, STBF awards tended to generate larger net aid gains for those with EFCs above the Pell cutoff.

Our "leveling up" hypothesis is supported by the pattern of subgroup treatment effects showing the largest gains for applicants whose enrollment rates are likely to be lowest in the absence of

\footnotetext{
${ }^{10}$ Effects here are estimated in 10 GPA bins of width 0.15 ranging from $2.50-2.64$ to $3.85-4.00$. The ACT bins correspond to single point scores ranging from the 10th to the 90th percentile of the score distribution in our sample.

${ }^{11}$ Table A5 compares OLS and logit specifications of estimates in subgroups. Logit marginal effects are virtually indistinguishable from the corresponding OLS estimates.
} 
treatment. We further substantiate this by showing how treatment effects vary with a single index of expected college persistence. As suggested by Abadie, Chingos and West (2013), such "endogenous stratification" estimates are best computed using leave-out fitted values. (Otherwise persistence outcomes are mechanically correlated with predicted persistence, which may bias estimates of causal effects, particularly at extreme predicted values.) In this case, we use the control group data to fit regressions

$$
Y_{j}=\pi_{(-i)}^{\prime} W_{j}+\varepsilon_{j} ; j \neq i
$$

for outcome $Y_{j}$ and covariates $W_{j}$ in leave-out samples omitting each observation $i$. The vector $W_{j}$ contains gender, race, parental education, EFC, family income, high school GPA, and composite ACT score - all strong predictors of persistence. The resulting leave-out fitted values are given by

$$
\hat{Y}_{i}=\hat{\pi}_{(-i)}^{\prime} W_{i}
$$

for each applicant in the control sample.

Estimates of the effect of STBF awards on four-year enrollment conditional on $\hat{Y}_{i}$ appear in panel A of Figure 5. This figure plots control group means for a range of $\hat{Y}_{i}$ running from 0.2 1.0 (excluding a small number of applicants with predicted enrollment rates outside this range.) Treatment group means are constructed as in Figures 1 to $4 .{ }^{12}$ Figure 5 reinforces the finding that scholarship effects are substantially larger for groups with lower predicted persistence. Among students whose expected year-two four-year enrollment rate falls below 30 percent, awards increased four-year enrollment by 30 points, nearly doubling the 35 percent enrollment rate in the control group. In the highest bin, the estimated treatment effect is a modest six points on a base of 86 percent. Again, we see considerable leveling up: the high-low gap in four-year college enrollment for the control group is 52 points, and Buffet awards cut this roughly in half.

In the same spirit, we also examined the relationship between conditional treatment effects and STBF reviewer assessments. These subjective ratings draw on personal essays and reference letters as well as quantitative criteria like grades and test scores. As Table 1 shows, reviewers tend to favor

\footnotetext{
${ }^{12}$ Note that predictions using leave-out means need not fit empirical conditional means perfectly, even if the underlying conditional mean function is correctly specified. This is evident in Figure 5 for predictions at low and high quantiles.
} 
applicants with higher ACT scores, higher GPAs, and lower family incomes. Here too, therefore, we might expect to see the same sort of negative relationship between reviewer predictions and program impacts seen in the pattern of treatment effects estimated conditional on fitted values from our empirical model of college readiness.

Treatment effects conditional on STBF reviewer scores are, indeed, negatively related with program impact. Scores are reported here on a seven-point scale. ${ }^{13}$ Among those ranked one to three (the bottom of the random assignment group), STBF awards boosted four-year enrollment in year two by 14 to 25 points. By contrast, among those ranked five to seven, estimated impacts were just 10 points, and only marginally significantly different from zero.

These results highlight a challenging trade-off between increasing program-induced gains and the desire to reward past achievement. Students who appear most meritorious based on grades and test scores are also those most likely to persist in college absent the STBF scholarship; this group is relatively skilled and highly motivated for post-secondary schooling. Conversely, awards made to groups of applicants who appear more likely to struggle in college benefit most dramatically from merit aid when they're lucky enough to get it.

\section{Bang for Buck Awarded}

STBF awards boosted college matriculation, with even larger effects on sophomore outcomes. Here, we compare these estimated gains with the associated scholarship costs. Specifically, to gauge cost effectiveness (bang for buck), we scale treatment effects using a two-stage least squares (2SLS) procedure that takes the endogenous variable to be STBF program spending. The 2SLS second stage equation in this case can be written

$$
Y_{i}=\beta A_{i}+\sum_{s, c} \rho_{s c} r_{i s c}+\lambda^{\prime} X_{i}+\varepsilon_{i}
$$

where the outcome, $Y_{i}$, is cumulative semesters of enrollment (through year two) at a given college type. The endogenous variable, $A_{i}$, is STBF aid received, measured in thousands of dollars. For students with full awards who attend NU, this includes the per pupil cost of LC services, estimated

\footnotetext{
${ }^{13}$ The raw reviewer scores for these students range from 15 to 21 ; we relabel these as one to seven in the figure. Two percent of students in the experimental group received scores either below 15 or above 21 . These students are excluded from the graph.
} 
to be $\$ 2,920$ in 2013 . As before, the model includes strata dummies, $r_{i s c}$, to account for differential awards rates across strata, and covariates, $X_{i}$, to increase precision. The instrument used to construct 2SLS estimates of equation (2) is a dummy for an STBF offer. The first stage for this 2SLS procedure is a version of Equation (1), with $A_{i}$ on the left hand side.

We interpret this 2SLS cost-benefit calculation using the potential outcomes and potential assignments notation introduced by Imbens and Angrist (1994). For each applicant (omitting $i$ subscripts), let $S$ indicate offers as before, and let $D_{2}(S)$ and $D_{4}(S)$ count the applicant's semesters of enrollment at two- and four-year schools. These are potential outcomes indexed by $S$. In other words, $D_{4}(1)$ counts an applicant's four-year semesters enrolled if offered a scholarship, and $D_{4}(0)$ counts four-year semesters enrolled if not offered an award. STBF spending, $A(S)$, is a potential treatment indexed by $S$. Potential outcomes and treatments are independent of aid offers, $S$, by virtue of random assignment.

Ignoring covariates, the first-stage effect of scholarship offers on program spending is $E[A(1)-$ $A(0)$ ]. Students not awarded scholarships generate no STBF spending, so $A(0)=0$. Scholarship winners receive $A(1)=c_{2} D_{2}(1)+c_{4} D_{4}(1)$ each, where $c_{2}$ and $c_{4}$ are per-term program costs at twoand four-year colleges, respectively (with $c_{2}<c_{4}$ ). We can therefore write the first stage for the impact of aid offers on program costs as follows:

$$
\begin{aligned}
E[A(1)-A(0)] & =E\left[c_{2} D_{2}(1)+c_{4} D_{4}(1)\right] \\
& =c_{2} E\left[D_{2}(1)-D_{2}(0)\right]+c_{4} E\left[D_{4}(1)-D_{4}(0)\right]+c_{2} E\left[D_{2}(0)\right]+c_{4} E\left[D_{4}(0)\right] \\
& \equiv c_{2} \Delta_{2}+c_{4} \Delta_{4}+\phi_{2}+\phi_{4} .
\end{aligned}
$$

Here, $\Delta_{2}$ and $\Delta_{4}$ denote treatment effects on semesters enrolled at two- and four-year schools, while $\phi_{2}$ and $\phi_{4}$ capture spending on two- and four-year enrollment that occurs in the absence of awards. The corresponding reduced form effect of aid offers on total semesters attended is therefore

$$
E\left[D_{2}(1)-D_{2}(0)\right]+E\left[D_{4}(1)-D_{4}(0)\right]=\Delta_{2}+\Delta_{4}
$$

As always, a just-identified instrumental variables estimand is given by the ratio of reduced form 
to first stage estimates. The 2SLS specification in (2) therefore estimates the ratio

$$
\beta_{\text {total }}^{2 S L S}=\frac{\Delta_{2}+\Delta_{4}}{c_{2} \Delta_{2}+c_{4} \Delta_{4}+\phi_{2}+\phi_{4}}
$$

The ratio of treatment effects to spending is readily computed, of course, but the 2SLS version of this calculation neatly adjusts for covariates and immediately provides appropriate standard errors for the ratio. The formulation in equation (5) also highlights the fact that $\phi_{2}$ and $\phi_{4}-$ money spent on enrollment that would have occurred with or without scholarships - are key determinants of bang for buck.

The overall first stage estimate for 2SLS estimates of equation (2) shows that STBF spent about $\$ 15,000$ per awarded applicant in the two years after award receipt. As can be seen in the first row of Table 7 , this overall spending figure varies across strata, reaching as high as about $\$ 18,000$ per applicant in the UNL stratum. (Bang for buck calculations for the community college stratum are not shown separately since treatment effects in this stratum are essentially zero).

The treatment effects generated by these expenditures, reported in panel B of Table 7, show gains in total semesters enrolled $\left(\Delta_{2}+\Delta_{4}\right)$ ranging from 0.29 in the UNL stratum to a high of 0.68 in the state college stratum. Gains in four-year enrollment $\left(\Delta_{4}\right)$ are largest in the UNO/UNK stratum: for these applicants, STBF awards generated nearly a full semester of additional enrollment by the end of year two. Importantly, in two out of three strata, gains in semesters enrolled reflect both an increase in four-year terms and a decline in two-year terms (that is, negative values of $\Delta_{2}$ ). The UNO/UNK stratum, for example, experienced almost a half a semester decrease in two-year enrollment. Only the state college stratum saw gains in both two- and four-year terms completed.

Buffett program spending increased net semesters attended by 0.025 per thousand dollars spent. In other words, STBF spent almost $\$ 40,000$ (\$1,000 divided by 0.025) for each added semester. Bang for buck is highest among students who targeted the least selective four-year colleges, a consequence of lower costs and larger treatment effects at these schools. Each semester's gain among applicants targeting UNL cost over $\$ 60,000$, while each semester gained generated program costs about half as large for those targeting UNO/UNK. Measured in terms of net semesters completed, bang for buck is largest among applicants targeting state colleges, a finding that reflects the fact that the treatment in this stratum increased two- as well as four-year enrollment. As suggested by our 
subgroup comparisons, the high costs of enrollment gains in the UNL stratum reflect the fact that applicants targeting UNL have high enrollment rates even without scholarship support. In terms of the 2SLS estimand (equation (5)) most spending on these students contributes to $\phi_{4}$ rather than $\Delta_{4}$

\subsection{Marginal Money}

The bang for buck estimates in Table 7 reveal that, because many scholarship awards leave their recipients' enrollment unchanged, the cost of increasing enrollment by a semester far exceeds the nominal award amounts $\left(c_{2}\right.$ or $\left.c_{4}\right)$. This feature of college aid was first highlighted in a pioneering analysis by Fuller, Manski and Wise (1983) of the federal Basic Educational Opportunity Grant (BEOG, later, known as Pell grants). Using a structural model of college choice estimated for a sample of high school seniors in 1972 (the National Longitudinal Study of the High School Class of 1972 data set), Fuller, Manski, and Wise simulate college enrollment rates by income group in the absence of the BEOG program. They estimate that a quarter of BEOG recipients were induced to go to college by the program, while three quarters would have enrolled with or without awards. Disaggregating by family income, 90 percent of BEOG awards made to students from middle and upper income families seem to have gone to students who would have enrolled anyway.

We would similarly like to isolate the marginal share of STBF spending, that is spending that changes behavior, either by increasing total enrollment or by shifting students across schools. At first blush, the terms $c_{2} \Delta_{2}+c_{4} \Delta_{4}$ in equation (4) would appear to capture marginal spending. Indeed, $c_{4} \Delta_{4}$, is marginal spending on four-year terms. But $c_{2} \Delta_{2}$ is a negative number in our data: this term mixes spending on increased two-year enrollment with the savings in two-year tuition from those who shifted from two- to four-year programs. Spending on the four-year enrollment increase generated by the latter group is accounted for in $c_{4} \Delta_{4}$. It remains, however, to extract an estimate of spending on new two-year enrollment from the gross change in two-year semesters. Otherwise, we overestimate the extent to which STBF awards are pure transfers. ${ }^{14}$

To facilitate the distinction between marginal and infra-marginal spending, we assume that

\footnotetext{
${ }^{14}$ Suppose, for example, that the scholarship switches 10 percent of students from two- to four-year schools and another 10 percent from no college to a two-year school. Suppose also that everyone who enrolls completes four semesters by the end of year two. In this case, marginal money is spending on the 20 percent of students who changed their behavior: $c_{2}(0.10 \times 4)+c_{4}(0.10 \times 4)$ But the net change in two-year enrollment, $\Delta_{2}$, is zero, so $c_{2} \Delta_{2}+c_{4} \Delta_{4}=c_{4}(0.10 \times 4)$ only.
} 
1. Aid doesn't reduce total terms enrolled for any applicant: $D_{4}(1)+D_{2}(1) \geq D_{4}(0)+D_{2}(0)$.

2. Aid doesn't reduce four-year terms enrolled for any applicant: $D_{4}(1)-D_{4}(0) \geq 0$.

3. There is no dual enrollment among scholarship winners: $D_{2}(1) D_{4}(1)=0$.

These assumptions allow aid offers to increase total terms enrolled and to shift students from two- to four-year institutions. However, they preclude the possibility that aid offers reduce total enrollment or shift students from four- to two-year programs.

It is useful at this point to define a binary indicator $d_{4}(1) \equiv \mathbf{1}\left\{D_{4}(1)>0\right\}$ that identifies students who enroll in four-year colleges when offered scholarships. We use this to split $c_{2} \Delta_{2}$ into two pieces:

$$
\begin{aligned}
c_{2} E\left[D_{2}(1)-D_{2}(0)\right] & =c_{2} E\left\{\left[D_{2}(1)-D_{2}(0)\right]\left[1-d_{4}(1)\right]\right\}+c_{2} E\left\{\left[D_{2}(1)-D_{2}(0)\right] d_{4}(1)\right\} \\
& =c_{2} E\left\{\left[D_{2}(1)-D_{2}(0)\right]\left[1-d_{4}(1)\right]\right\}-c_{2} E\left[D_{2}(0) d_{4}(1)\right] .
\end{aligned}
$$

The first term here captures increased spending on new two-year enrollment, while the second captures reductions in two-year spending due to shifting from two- to four-year schools. (The second equality follows from Assumption 3, which requires that $D_{2}(1) d_{4}(1)=0$, meaning treated students don't simultaneously enroll in two- and four-year colleges.) Substituting equation (6) into the first stage expression in (3) and combining like terms provides a useful decomposition of the aid first stage:

$$
\begin{aligned}
E[A(1)-A(0)]=c_{2} E & \left\{D_{2}(0)\left[1-d_{4}(1)\right]\right\}+c_{4} E\left[D_{4}(0)\right] \\
& +c_{2} E\left\{\left[D_{2}(1)-D_{2}(0)\right]\left[1-d_{4}(1)\right]\right\}+c_{4} E\left[D_{4}(1)-D_{4}(0)\right] .
\end{aligned}
$$

Equation (7) distinguishes four types of spending:

1. $c_{2} E\left\{D_{2}(0)\left[1-d_{4}(1)\right]\right\}$ is spending on two-year enrollment that occurs with or without awards. (This term is positive when $D_{2}(0)>0$ and $d_{4}(1)=0$, that is, for students who attend two year-colleges without awards but don't attend four-year colleges with awards.)

2. Similarly, $c_{4} E\left[D_{4}(0)\right]$ is spending on four-year enrollment that occurs with or without awards. 
(Students for whom $D_{4}(0) \neq 0$ attend four-year colleges in the absence of awards. By Assumption 2, they must also attend four-year colleges if awarded scholarships.)

3. $c_{2} E\left\{\left[D_{2}(1)-D_{2}(0)\right]\left[1-d_{4}(1)\right]\right\}$ is spending on new two-year enrollment among students who do not attend four-year colleges when awarded scholarships (that is, students for whom $\left.d_{4}(1)=0\right)$.

4. $c_{4} E\left[D_{4}(1)-D_{4}(0)\right]$ is spending on the increase in four-year enrollment generated by awards. (This follows from Assumption 2, which says that $D_{4}(1)-D_{4}(0)$ must be non-negative.) This term includes new enrollment, enrollment that's shifted from two- to four-year programs, and increased four-year enrollment among students who would have otherwise attended fewer four-year terms.

Terms 1 and 2 above capture spending on enrollment that is unchanged by awards and is therefore infra-marginal. The remaining two terms reflect spending on new two-year and four-year enrollment, that is, marginal money. The sum of these marginal terms is

$$
c_{2} E\left\{\left[D_{2}(1)-D_{2}(0)\right]\left[1-d_{4}(1)\right]\right\}+c_{4} E\left[D_{4}(1)-D_{4}(0)\right] \equiv c_{2} \mu+c_{4} \Delta_{4}
$$

Marginal money due to four-year spending is simply $c_{4} \Delta_{4}$, a quantity easily computed. But $c_{2} \mu$ isn't non-parametrically identified because we don't observe the joint outcome $\mu \equiv\left[D_{2}(1)-D_{2}(0)\right]\left[1-d_{4}(1)\right] .{ }^{15}$ We therefore construct bounds under alternative assumptions about two-year enrollment in the absence of award offers. In pursuit of these bounds, it helps to rewrite $\mu$ as follows:

$$
\begin{aligned}
\mu & \equiv E\left\{\left[D_{2}(1)-D_{2}(0)\right]\left[1-d_{4}(1)\right]\right\} \\
& =E\left[D_{2}(1)-D_{2}(0) \mid d_{4}(1)=0\right] E\left[1-d_{4}(1)\right] .
\end{aligned}
$$

Given Assumptions 1 and 2, this term is bounded below by zero: the scholarship can only increase two-year enrollment among students who would never attend four-year schools. We obtain an upper bound for $\mu$ by assuming that all two-year enrollment among those who would never attend four-

\footnotetext{
${ }^{15}$ As always, we observe the marginal distribution of potential outcomes, $D_{2}(S)$ and $D_{4}(S)$, but not their joint distribution. Here, for example, whether a treated four-year college student would have attended a two-year school in the absence of treatment.
} 
year schools is induced by awards. This in turn implies $D_{2}(0)=0$ for all those with $d_{4}(1)=0$, in which case $\mu=E\left[D_{2}(1) \mid d_{4}(1)=0\right] E\left[1-d_{4}(1)\right]$. The resulting marginal money bounds are

$$
M(\mu) \equiv \frac{c_{2} \mu+c_{4} \Delta_{4}}{c_{2} \Delta_{2}+c_{4} \Delta_{4}+\phi_{2}+\phi_{4}}
$$

for $\mu \in\left\{0, E\left[D_{2}(1) \mid d_{4}(1)=0\right] E\left[1-d_{4}(1)\right]\right\}$.

As can be seen in panel $\mathrm{C}$ of Table 7, marginal money is estimated to fall between about 14 and 19 percent of total program spending. Thus, like Fuller, Manski and Wise (1983), most of the financial aid awarded through Buffett scholarships goes to applicants whose behavior is unchanged in response to an award. The largest marginal money share, between 22 and 23 percent of total spending, is for applicants in the UNO/UNK stratum. This finding reflects the especially large program-induced boost in relatively expensive four-year enrollment found for applicants targeting the UNO and UNK campuses. By contrast, the large bang for buck for state college applicants seen in panel $\mathrm{C}$ of the table doesn't translate into a large marginal money share for this group. The discrepancy between the bang for buck and marginal money statistics among state college applicants is explained by the fact that half of the bang for buck figure in the state college stratum comes from spending on relatively inexpensive two-year colleges. Spending on four-year support in the state college stratum was mostly infra-marginal. Policy-makers who value four-year enrollment over two-year enrollment might therefore see support of applicants to NU's least selective campuses as being most cost-effective.

\section{Distinguishing Aid Effects from Learning Communities}

As we've seen, STBF awards made to students targeting NU generated larger initial gains in fouryear enrollment than did STBF offers made to students who targeted state and community colleges. To what extent is this result a reflection of the LC support offered to Buffet scholars at NU? The second arm of our randomized evaluation quantifies the contribution of LC by offering a second aidonly treatment, known to applicants as the College Opportunity Scholarship (COS). COS awards, which were first offered to the 2013 cohort, match the aid component of full awards without offering access to the LC services enjoyed by Buffett Scholars at NU. Paralleling the LC-including treatment, COS awards were made only to applicants targeting an NU campus. 
Table 8 offers a first look at treatment effects for the COS intervention, comparing these with estimates for the group of 2013 applicants who targeted NU and were offered full awards. This table also reports preliminary results for a few second-year outcomes for the 2013 cohort; we expect to expand the list of outcomes as well as the COS sample in the near future. These initial findings show COS treatment effects close to, though somewhat below, those generated by full awards. Estimates of the difference in effects generated by full and COS awards are not significantly different from zero.

Because the COS experimental cohort has faced only one full year of potential college enrollment to date, comparisons between COS and traditional STBF awards are provisional. We expect to be able to sharpen these findings in the near future, as more data on enrollments in the academic year 2014-15 become available.

\section{Summary and Conclusions}

STBF awards induced a clear shift from two- to four-year schools and a marked increase in secondyear college enrollment. These gains are driven by strong persistence among award winners, coupled with high rates of attrition in the control group. Second-year gains and shifts into four-year programs are largest for nonwhite applicants, for those with relatively low ACT scores, and for applicants who indicated an interest in four-year programs other than the most-selective Nebraska public college. Scholarships generated the largest enrollment and persistence gains in demographic groups that would otherwise have been predicted to fare poorly - that is, they enabled disadvantaged students to 'level up.' These findings highlight the paradox of merit aid: awards based on past achievement are likely to generate smaller gains than awards made to applicants who appear less likely to be college-ready.

These results are preliminary and limited to outcomes available in a two-year follow-up. As the current cohorts age and new cohorts enter the study, we expect to be able to examine effects on longer-term persistence and college completion. We also anticipate a sharpening of the contrast between estimates of the effects of aid offered with Learning Community services and estimates of the effects of aid alone. Evidence on differential effects across subgroups and, in particular, the pattern that shows larger gains for less well-prepared students, should also grow more conclusive. 
Ultimately, we expect to be able to measure effects in the labor market as well as on completed schooling. 


\section{References}

Abadie, Alberto, Matthew M. Chingos, and Martin R. West. 2013. "Endogenous Stratification in Randomized Experiments." National Bureau of Economic Research Working Paper 19742, December.

Abraham, Katharine G., and Melissa A. Clark. 2006. "Financial Aid and Students' College Decisions Evidence from the District of Columbia Tuition Assistance Grant Program." Journal of Human Resources, 41(3): 578-610.

Angrist, Joshua D., Daniel Lang, and Philip Oreopoulos. 2009. "Incentives and Services for College Achievement: Evidence from a Randomized Trial." American Economic Journal: Applied Economics, 1(1): 136-163.

Angrist, Joshua D., Philip Oreopoulos, and Tyler Williams. 2014. "When Opportunity Knocks, Who Answers? New Evidence on College Achievement Awards." Journal of Human Resources, 49(3): 572-610.

Arcidiacono, Peter, Esteban M. Aucejo, and V. Joseph Hotz. 2016. "University Differences in the Graduation of Minorities in STEM Fields: Evidence from California." American Economic Review, 106(3): 525-562.

Avery, Christopher, Caroline M. Hoxby, Clement Jackson, Kaitlin Burek, and Glenn Pope. 2006. "Cost Should Be No Barrier: An Evaluation of the First Year of Harvard's Financial Aid Initiative." National Bureau of Economic Research Working Paper 12029, February.

Bettinger, Eric P., and Rachel Baker. 2014. "The Effects of Student Coaching in College: An Evaluation of a Randomized Experiment in Student Mentoring." Educational Evaluation and Policy Analysis, 36(1): 3-19.

Bloom, Dan, and Colleen Sommo. 2005. "Building Learning Communities: Early Results from the Opening Doors Demonstration at Kingsborough Community College.” MDRC report, June. Available at http://www.mdrc.org/publication/building-learning-communities (accessed March $10,2017)$. 
Bound, John, and Sarah E. Turner. 2002. "Going to War and Going to College: Did World War II and the G.I. Bill Increase Educational Attainment for Returning Veterans?" Journal of Labor Economics, 20(4): 784-815.

Cohodes, Sarah R., and Joshua S. Goodman. 2014. "Merit Aid, College Quality, and College Completion: Massachusetts' Adams Scholarship as an In-Kind Subsidy." American Economic Journal: Applied Economics, 6(4): 251-285.

College Board. 2014. "Maximum and Average Pell Grant Over Time." Available at http://trends.collegeboard.org/student-aid/figures-tables/fed-aid-maximum-and-averagepellgrant-over-time (accessed December 1, 2014).

Congressional Budget Office. 2013. "The Federal Pell Grant Program: Recent Growth and Policy Options." CBO Publication 4451, September. Available at http://www.cbo.gov/sites/default/files/cbofiles/attachments/44448_PellGrants_9-5-13.pdf (accessed March 16, 2017).

Cornwell, Christopher, David B. Mustard, and Deepa J. Sridhar. 2006. "The Enrollment Effects of Merit-Based Financial Aid: Evidence from Georgia's HOPE Program." Journal of Labor Economics, 24(4): 761-786.

Deming, David, and Susan Dynarski. 2009. "Into College, Out of Poverty? Policies to Increase the Postsecondary Attainment of the Poor." National Bureau of Economic Research Working Paper 15387, September.

Dynarski, Susan M. 2000. "Hope for Whom? Financial Aid for the Middle Class and Its Impact on College Attendance." National Tax Journal, 53(3): 629-662.

Dynarski, Susan M. 2004. "The New Merit Aid." In College Choices: The Economics of Where to Go, When to Go, and How to Pay For It. Vol. I, eds. Caroline M. Hoxby, 67-93. Chicago: University of Chicago Press.

Dynarski, Susan M., Steven W. Hemelt, and Joshua M. Hyman. 2015. "The Missing Manual: Using National Student Clearinghouse Data to Track Postsecondary Outcomes." Educational Evaluation and Policy Analysis, 37: 53S-79S. 
Fuller, Win, Charles F. Manski, and David A. Wise. 1983. "Enrollment Effects of the BEOG Program." In College Choice in America. eds. Charles F. Manski, and David A. Wise, Chapter 7, 118-128. Cambridge: Harvard University Press.

Goldrick-Rab, Sara, Robert Kelchen, Douglas N. Harris, and James Benson. 2016. "Reducing Income Inequality in Educational Attainment: Experimental Evidence on the Impact of Financial Aid on College Completion." American Journal of Sociology, 121(6): 1762-1817.

Goodman, Joshua S. 2008. "Who Merits Financial Aid?: Massachusetts' Adams Scholarship." Journal of Public Economics, 92(10): 2121-2131.

Imbens, Guido W., and Joshua D. Angrist. 1994. "Identification and Estimation of Local Average Treatment Effects." Econometrica, 62(2): 467-475.

Kane, Thomas J. 2003. "A Quasi-Experimental Estimate of the Impact of Financial Aid on College-Going." National Bureau of Economic Research Working Paper 9703, May.

Kane, Thomas J. 2007. "Evaluating the Impact of the D.C. Tuition Assistance Grant Program." Journal of Human Resources, 42(3): 555-582.

Leslie, Larry L., and Paul T. Brinkman. 1987. "Student Price Response in Higher Education: The Student Demand Studies." The Journal of Higher Education, 58(2): 181 - 204.

Marx, Benjamin M., and Lesley J. Turner. 2015. "Borrowing Trouble? Student Loans, the Cost of Borrowing, and Implications for the Effectiveness of Need-Based Grant Aid." National Bureau of Economic Research Working Paper 20850, January.

U.S. Department of Education. 2012. "Federal Student Aid Handbook." Office of Federal Student Aid. Available at https://ifap.ed.gov/ifap/byAwardYear.jsp?type=fsahandbook\&awardyear=2012-2013 (accessed December 21, 2016).

Weiss, Michael J., Alexander Mayer, Dan Cullinan, Alyssa Ratledge, Colleen Sommo, and John Diamond. 2015a. "A Random Assignment Evaluation of Learning Communities at Kingsborough Community College: Seven Years Later." Journal of Research on Educational Effectiveness, 8(2): 189-217. 
Weiss, Michael J., Mary G. Visher, Evan Weissman, and Heather D. Wathington. $2015 b$. "The Impact of Learning Communities for Students in Developmental Education: A Synthesis of Findings from Randomized Trials at Six Community Colleges." Education Evaluation and Policy Analysis, 37(4): 520-541. 
Table 1

Descriptive Statistics

(2012 \& 2013 Cohorts)

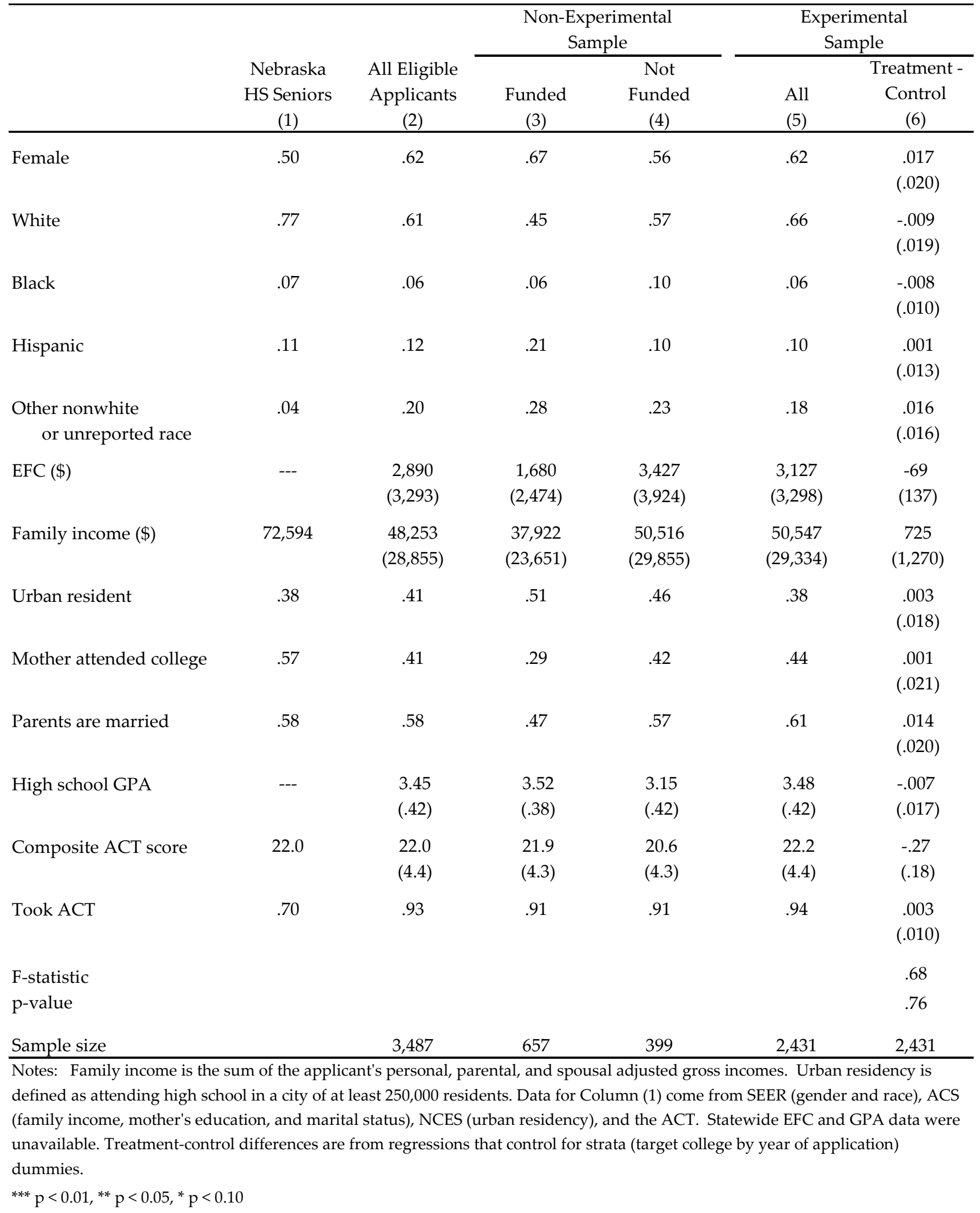


Table 2

Effect on Year One Financial Aid Packages

for Nebraska Public College Students

(2012 \& 2013 Cohorts)

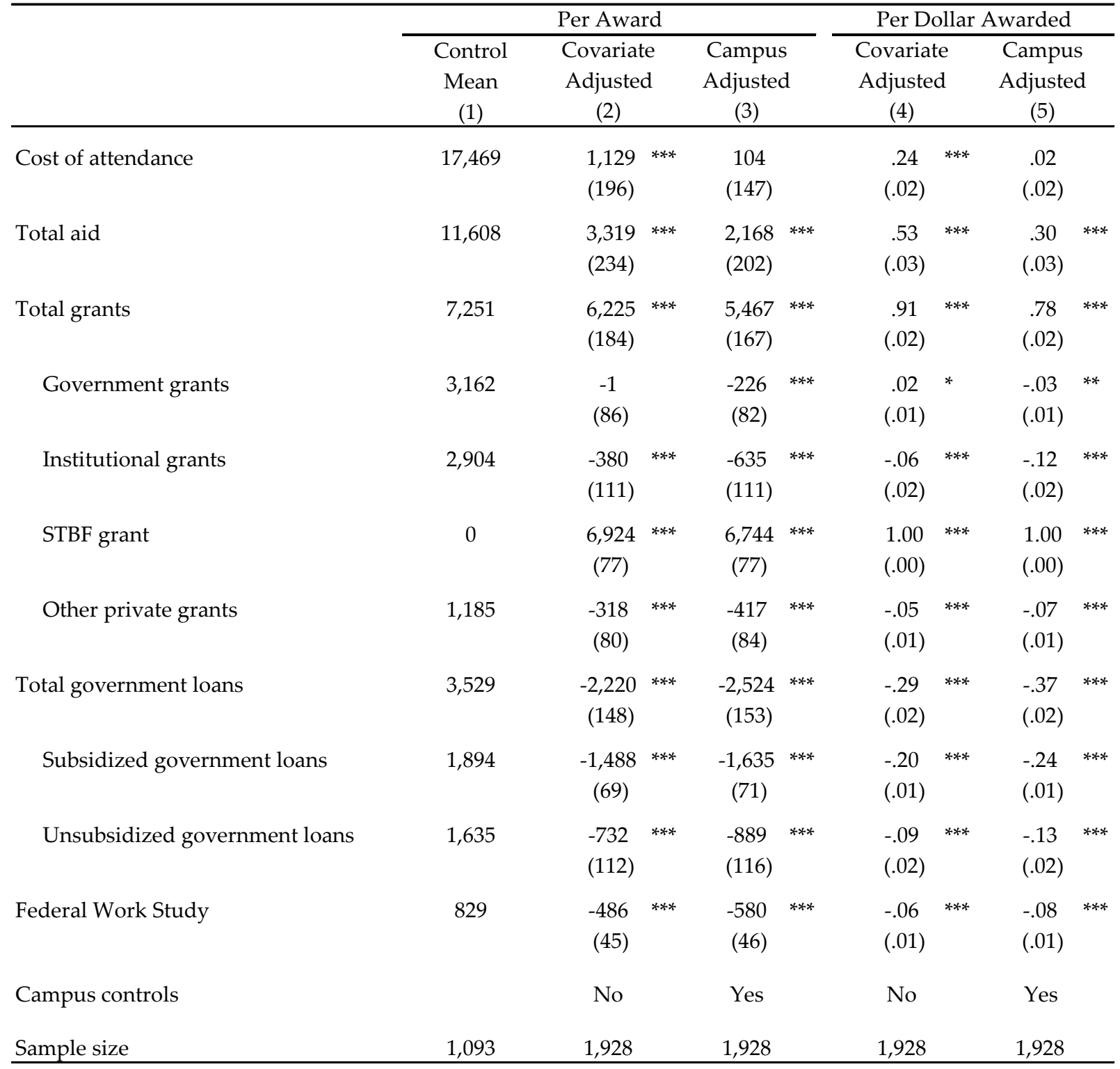

Notes: This table reports effects of the STBF scholarship offer on students' financial aid packages. The sample is restricted to students enrolled in Nebraska public colleges. Aid data are currently unavailable for the 309 students at state colleges and Mid-Plains Community College. Columns (2) and (3) report results from regressions of the financial aid awarded in each category on a dummy for winning a scholarship, while Columns (4) and (5) report results from regressions of the same dependent variables on the dollar value of scholarships awarded. The regressions in Columns (3) and (5) control for cumulative enrollment at each campus. All regressions control for target college, cohort, and baseline covariates. Baseline covariates include high school GPA and EFC, as well as bins for family income and ACT composite score. Government grants include federal and state grants. Government loans include subsidized and unsubsidized loans, where subsidized is the sum of Perkins and subsidized Stafford loans, and unsubsidized is the sum of PLUS and unsubsidized Stafford loans.

${ }^{* * *} \mathrm{p}<0.01,{ }^{* *} \mathrm{p}<0.05,{ }^{*} \mathrm{p}<0.10$ 
Table 3

Effect on Year Two Financial Aid Packages

for Nebraska Public College Students

(2012 Cohort)

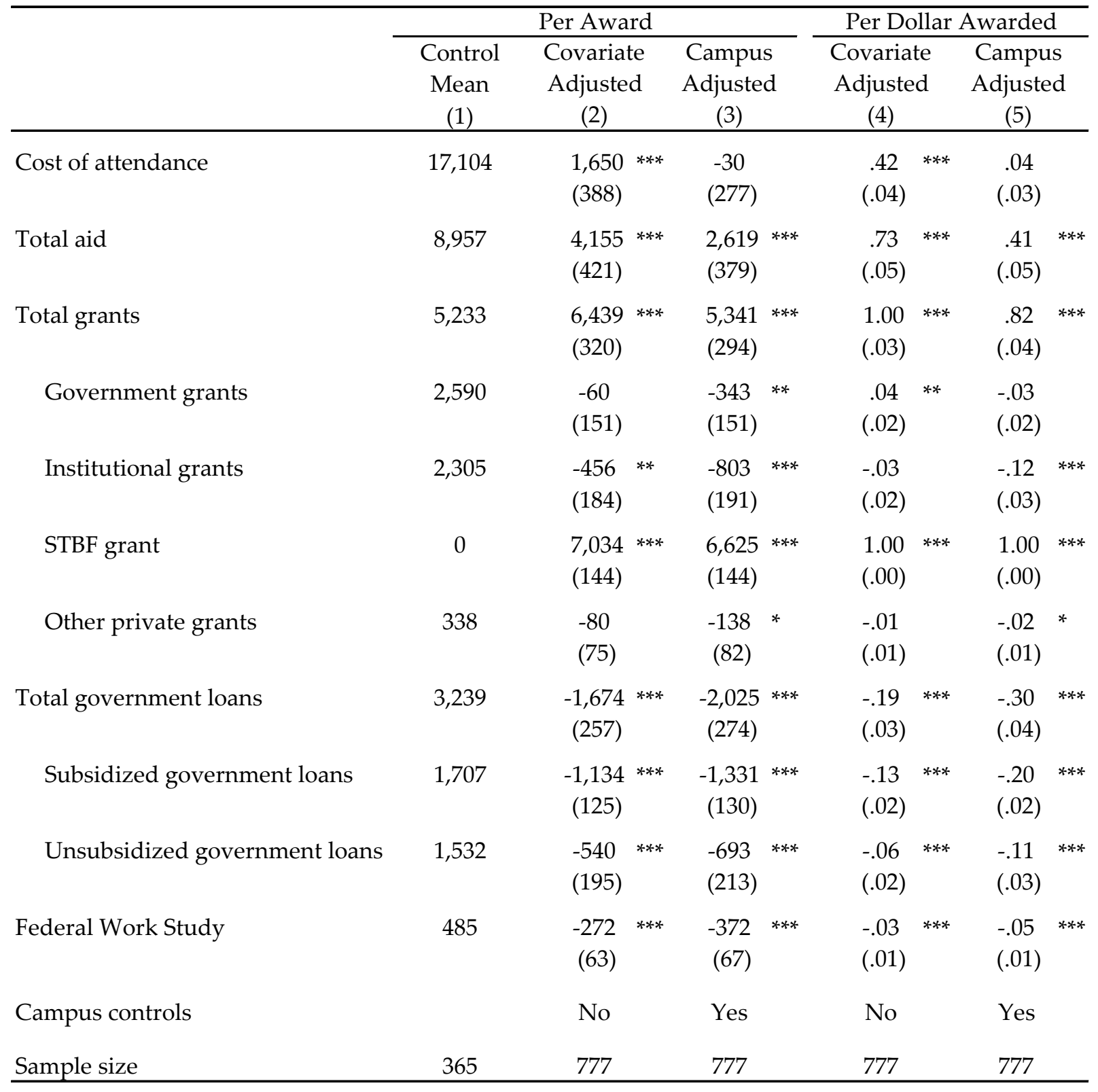

Notes: Variables and specifications are defined in Table 2. The sample is restricted to students enrolled in Nebraska public colleges from the 2012 cohort, where we have two complete years of outcome data. Aid data are currently unavailable for the 94 students at state colleges and Mid-Plains Community College.

*** $\mathrm{p}<0.01,{ }^{* *} \mathrm{p}<0.05,{ }^{*} \mathrm{p}<0.10$ 


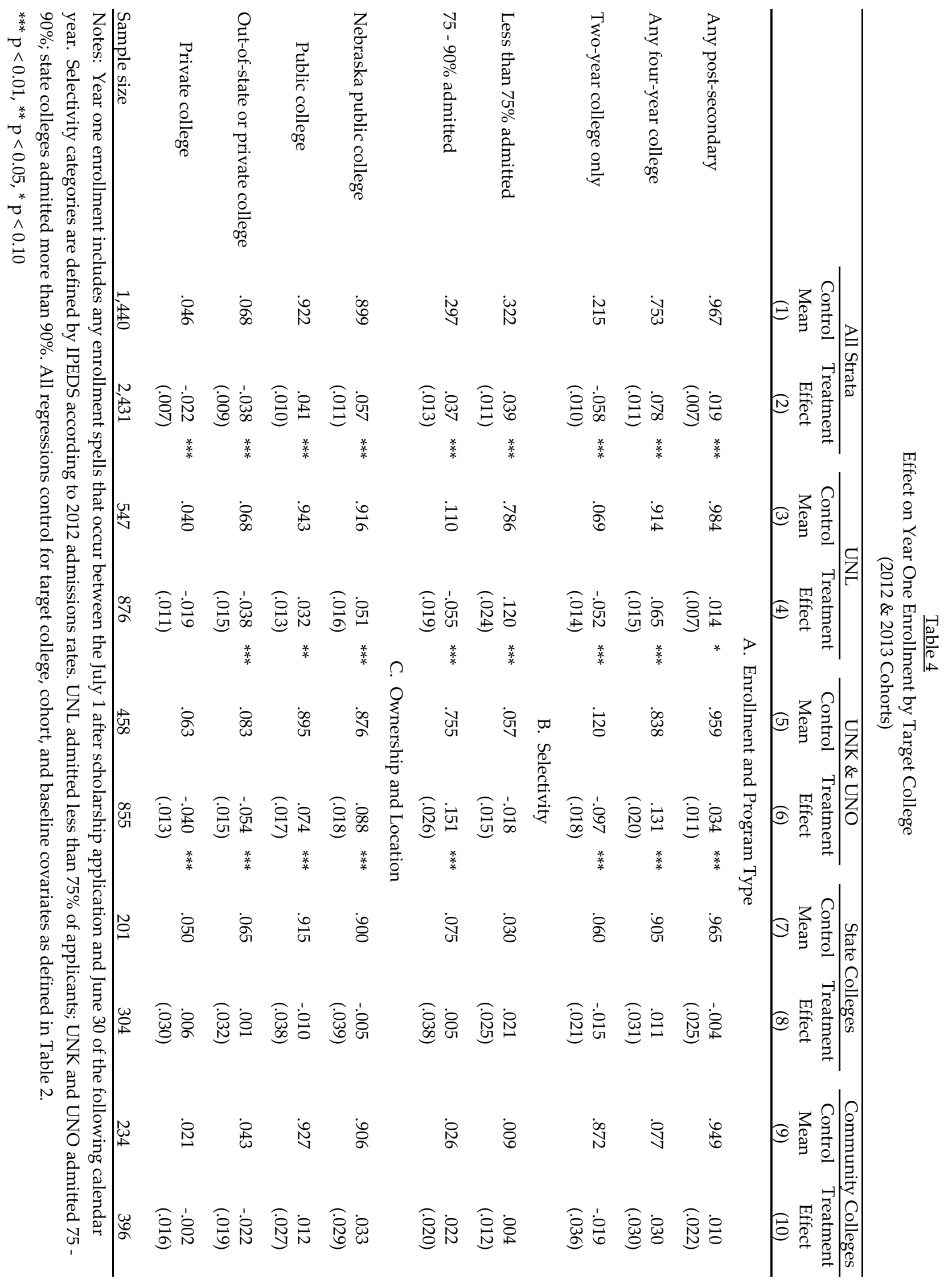




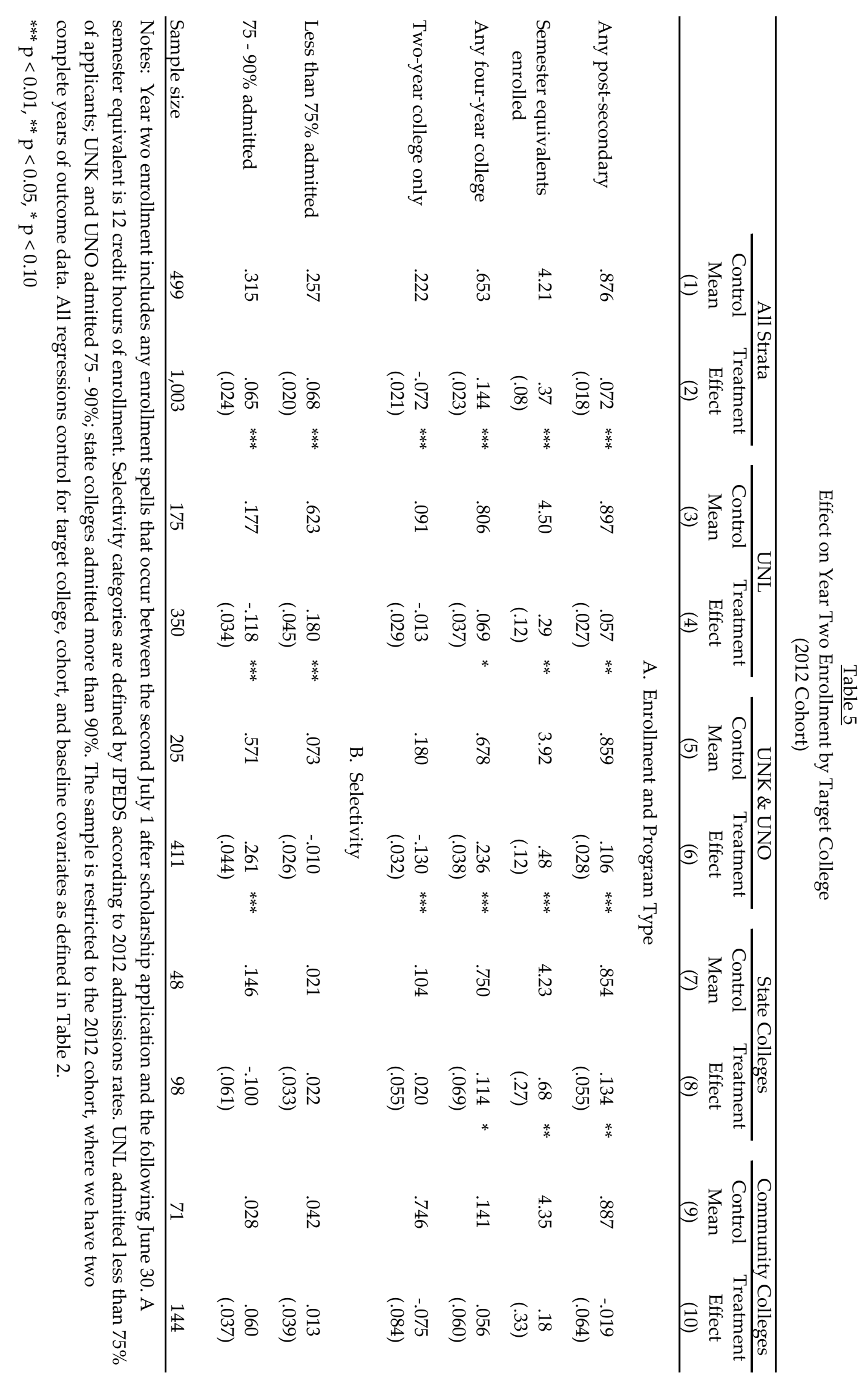


$\underline{\text { Table } 6}$

Effect on Retention

(2012 Cohort)

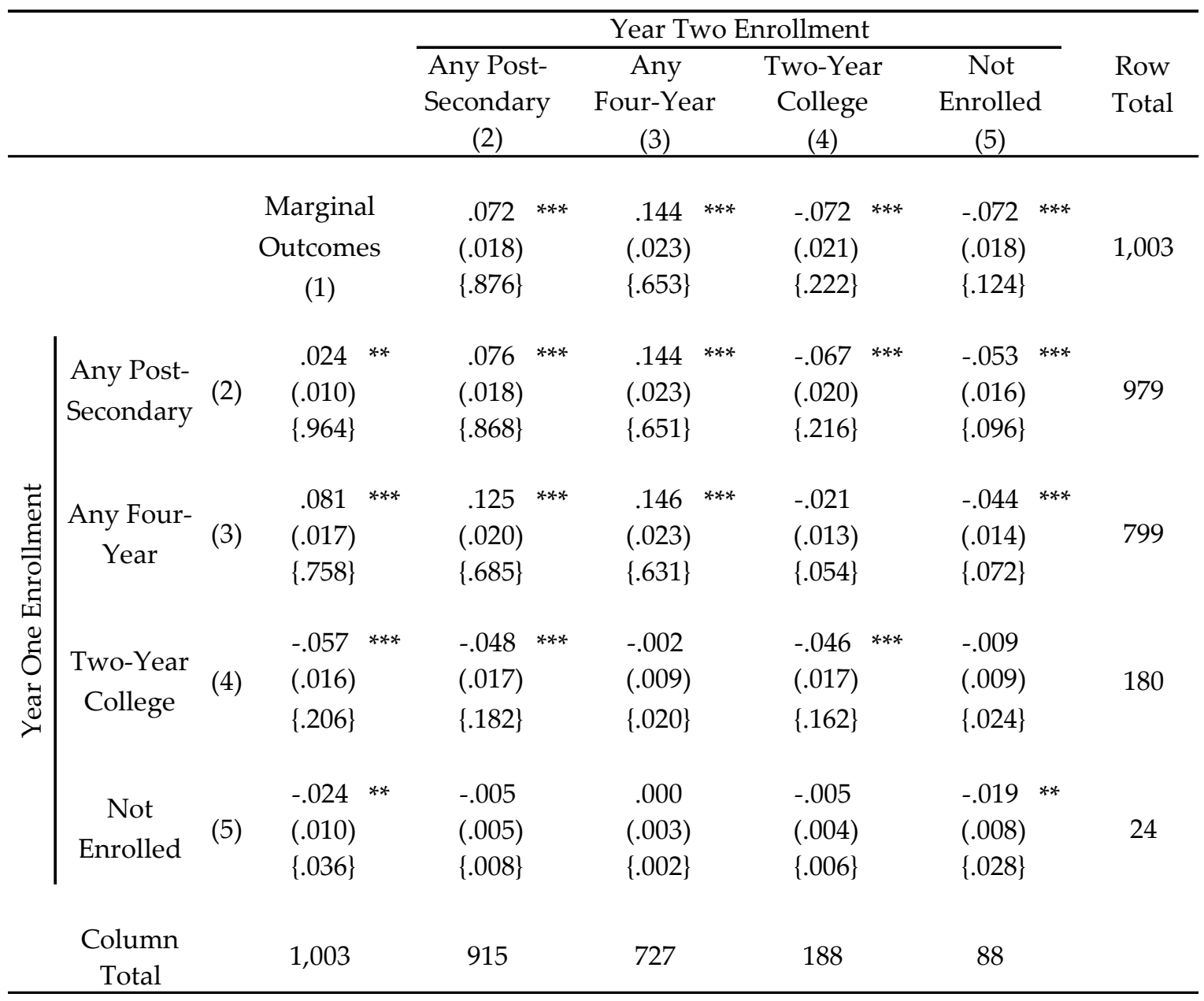

Notes: Year one enrollment includes any enrollment spells that occur between the July 1 after scholarship application and June 30 of the following calendar year. Year two enrollment includes any enrollment spells that occur between the subsequent July 1 and June 30 . This table shows treatment effects on joint year one and year two outcomes, e.g., any four-year enrollment in both years. Standard errors are in parentheses, and control means for the given outcomes are in braces. Row and column totals report counts for year one and year two outcomes, respectively. The sample is restricted to the 2012 cohort, where we have two complete years of outcome data. All regressions control for target college, cohort, and baseline covariates as defined in Table 2.

${ }^{* * *} \mathrm{p}<0.01,{ }^{* *} \mathrm{p}<0.05,{ }^{*} \mathrm{p}<0.10$ 
Table 7

Cost Effectiveness Through Year Two

(2012 Cohort)

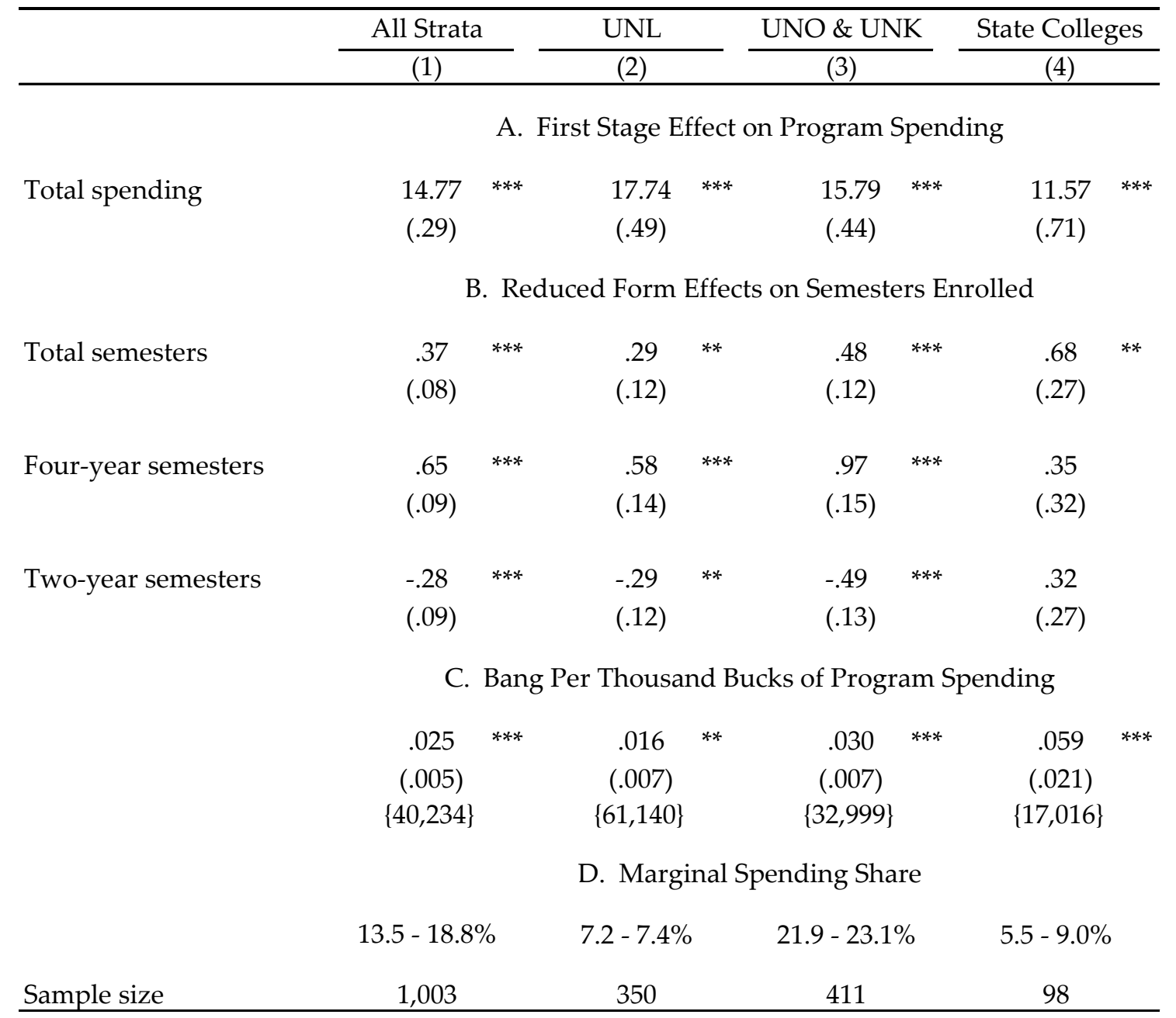

Notes: Panel A reports first stage regressions of program spending on a dummy for the STBF

scholarship offer. Program spending is measured in thousands of dollars and includes both scholarship money and the per pupil cost of LC services for NU students. Panel B reports the corresponding reduced form effects on semester equivalents, as defined in Table 5, and Panel C reports the associated 2SLS estimates. The average cost of each added semester---equal to $\$ 1,000$ divided by the 2SLS point estimate--is reported in braces. Panel D presents the marginal money estimates detailed in Section 7. The sample is restricted to the 2012 cohort, where we have two complete years of outcome data. All regressions control for target college, cohort, and baseline covariates as defined in Table 2.

${ }^{* * *} \mathrm{p}<0.01,{ }^{* *} \mathrm{p}<0.05,{ }^{*} \mathrm{p}<0.10$ 


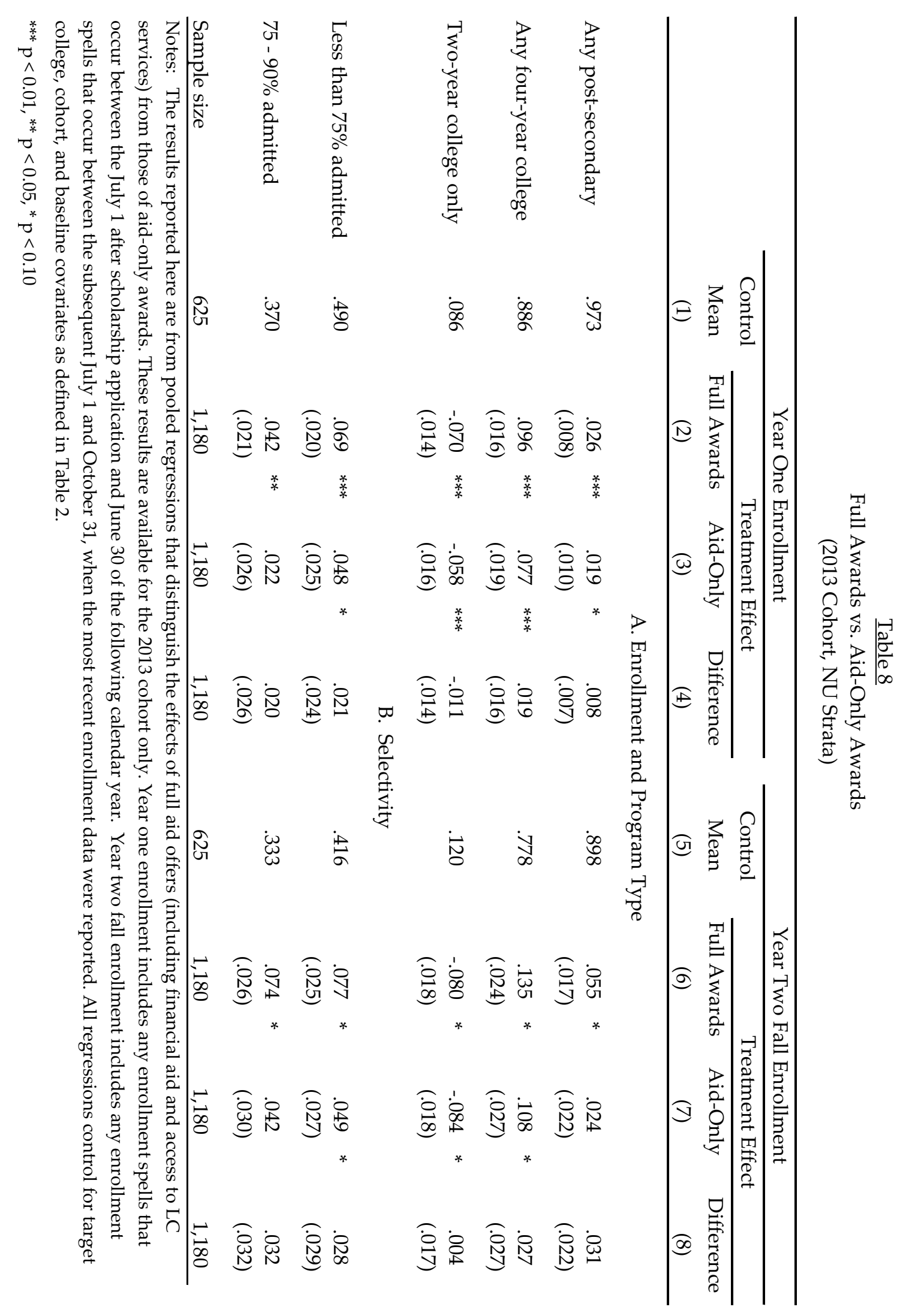




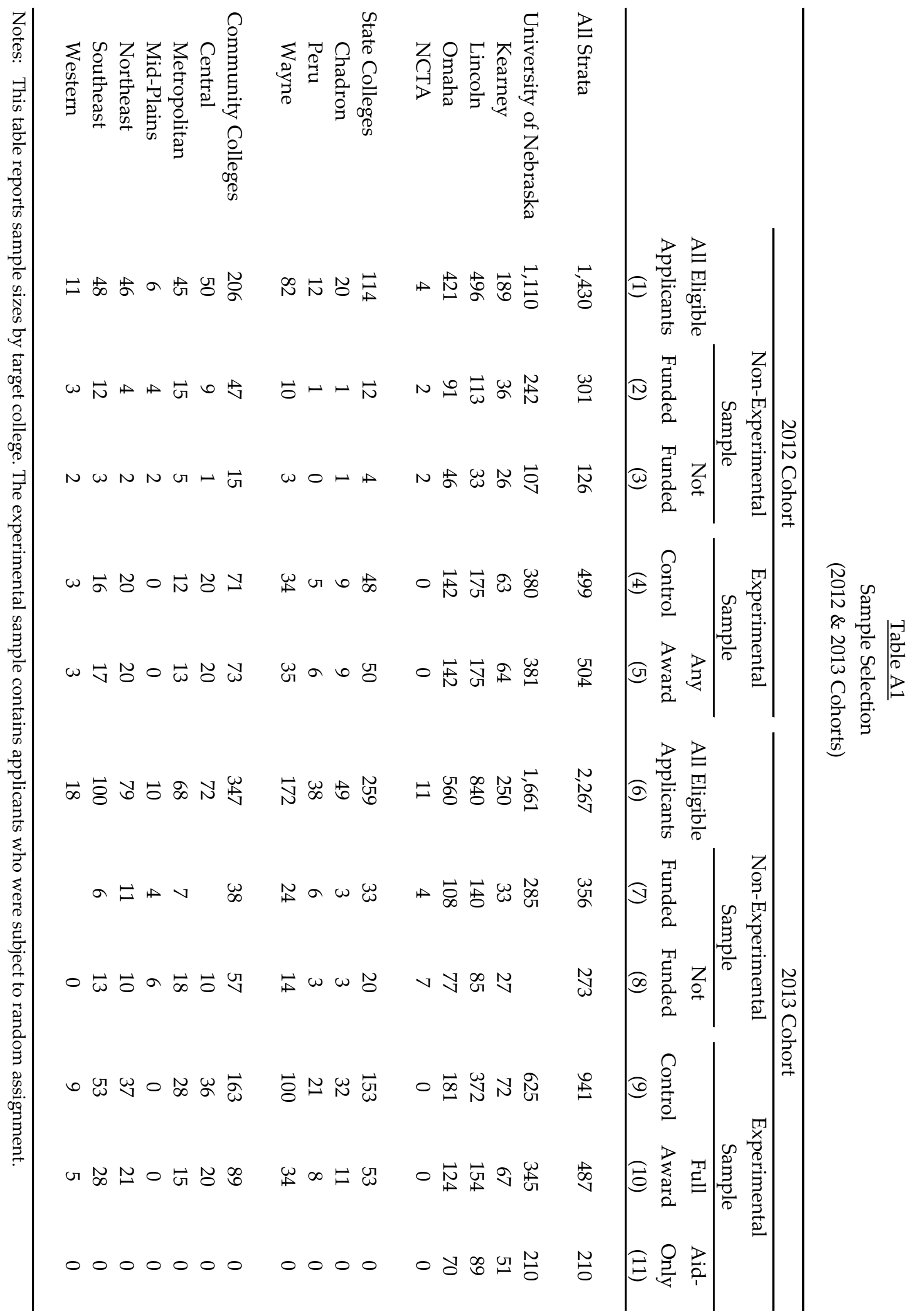


Table A2

Descriptive Statistics: Cohort Comparison

Experimental Samples

\begin{tabular}{|c|c|c|c|c|c|c|}
\hline & \multicolumn{2}{|c|}{2012 Cohort } & \multicolumn{4}{|c|}{2013 Cohort } \\
\hline & \multirow[b]{2}{*}{$\begin{array}{l}\text { All } \\
(1)\end{array}$} & \multirow[b]{2}{*}{$\begin{array}{c}\text { Treatment - } \\
\text { Control } \\
(2) \\
\end{array}$} & \multicolumn{2}{|c|}{ Full Award } & \multicolumn{2}{|c|}{ Aid-Only } \\
\hline & & & $\begin{array}{l}\text { All } \\
\text { (3) }\end{array}$ & $\begin{array}{c}\text { Treatment- } \\
\text { Control } \\
(4) \\
\end{array}$ & $\begin{array}{l}\text { All } \\
(5)\end{array}$ & $\begin{array}{c}\text { Treatment- } \\
\text { Control } \\
(6) \\
\end{array}$ \\
\hline Female & .62 & $\begin{array}{l}.009 \\
(.031)\end{array}$ & .61 & $\begin{array}{l}.024 \\
(.027)\end{array}$ & .60 & $\begin{array}{l}-.036 \\
(.040)\end{array}$ \\
\hline White & .66 & $\begin{array}{l}.031 \\
(.028)\end{array}$ & .66 & $\begin{array}{l}-.041 \\
(.027)\end{array}$ & .64 & $\begin{array}{l}-.055 \\
(.039)\end{array}$ \\
\hline Black & .08 & $\begin{array}{l}-.011 \\
(.017)\end{array}$ & .05 & $\begin{array}{l}-.006 \\
(.012)\end{array}$ & .06 & $\begin{array}{l}.006 \\
(.020)\end{array}$ \\
\hline Hispanic & .11 & $\begin{array}{l}-.009 \\
(.019)\end{array}$ & .10 & $\begin{array}{l}.009 \\
(.017)\end{array}$ & .10 & $\begin{array}{l}-.001 \\
(.025)\end{array}$ \\
\hline $\begin{array}{l}\text { Other nonwhite race } \\
\text { or unreported race }\end{array}$ & .15 & $\begin{array}{l}-.011 \\
(.022)\end{array}$ & .19 & $\begin{array}{l}.037 \\
(.023)\end{array}$ & .20 & $\begin{array}{l}.050 \\
(.034)\end{array}$ \\
\hline $\mathrm{EFC}(\$)$ & 3,366 & $\begin{array}{c}-52 \\
(235)\end{array}$ & 2,960 & $\begin{array}{c}-83 \\
(161)\end{array}$ & 3,032 & $\begin{array}{c}213 \\
(240)\end{array}$ \\
\hline Family income & 50,564 & $\begin{array}{c}339 \\
(2,170)\end{array}$ & 50,535 & $\begin{array}{r}1,026 \\
(1,501)\end{array}$ & 51,397 & $\begin{array}{c}4,623 * \\
(2,394)\end{array}$ \\
\hline Urban resident & .42 & $\begin{array}{l}-.007 \\
(.027)\end{array}$ & .35 & $\begin{array}{l}.010 \\
(.024)\end{array}$ & .41 & $\begin{array}{l}.006 \\
(.037)\end{array}$ \\
\hline Mother attended college & .43 & $\begin{array}{l}.024 \\
(.031)\end{array}$ & .45 & $\begin{array}{l}-.017 \\
(.028)\end{array}$ & .47 & $\begin{array}{c}.033 \\
(.040)\end{array}$ \\
\hline Parents are married & .58 & $\begin{array}{l}-.010 \\
(.031)\end{array}$ & .63 & $\begin{array}{l}.032 \\
(.027)\end{array}$ & .63 & $\begin{array}{l}.056 \\
(.038)\end{array}$ \\
\hline High school GPA & 3.44 & $\begin{array}{l}.005 \\
(.026)\end{array}$ & 3.51 & $\begin{array}{l}-.017 \\
(.022)\end{array}$ & 3.57 & $\begin{array}{l}.022 \\
(.031)\end{array}$ \\
\hline Composite ACT score & 21.9 & $\begin{array}{l}-.37 \\
(.27)\end{array}$ & 22.5 & $\begin{array}{l}-.19 \\
(.24)\end{array}$ & 23.3 & $\begin{array}{l}-.45 \\
(.38)\end{array}$ \\
\hline Took ACT & .06 & $\begin{array}{l}-.002 \\
(.015)\end{array}$ & .06 & $\begin{array}{l}-.005 \\
(.012)\end{array}$ & .03 & $\begin{array}{l}-.012 \\
(.013)\end{array}$ \\
\hline F-statistic & & .44 & & .84 & & 1.27 \\
\hline p-value & & .94 & & .60 & & .23 \\
\hline Sample size & 1,003 & 1,003 & 1,428 & 1,428 & 835 & 835 \\
\hline
\end{tabular}

Notes: Variable definitions and specifications are detailed in Table 1 . The 2013 aid-only sample contains the NU strata only and excludes students who were offered full awards.

${ }^{* * *}$ p $<0.01,{ }^{* *}$ p $<0.05,{ }^{*}$ p $<0.10$ 


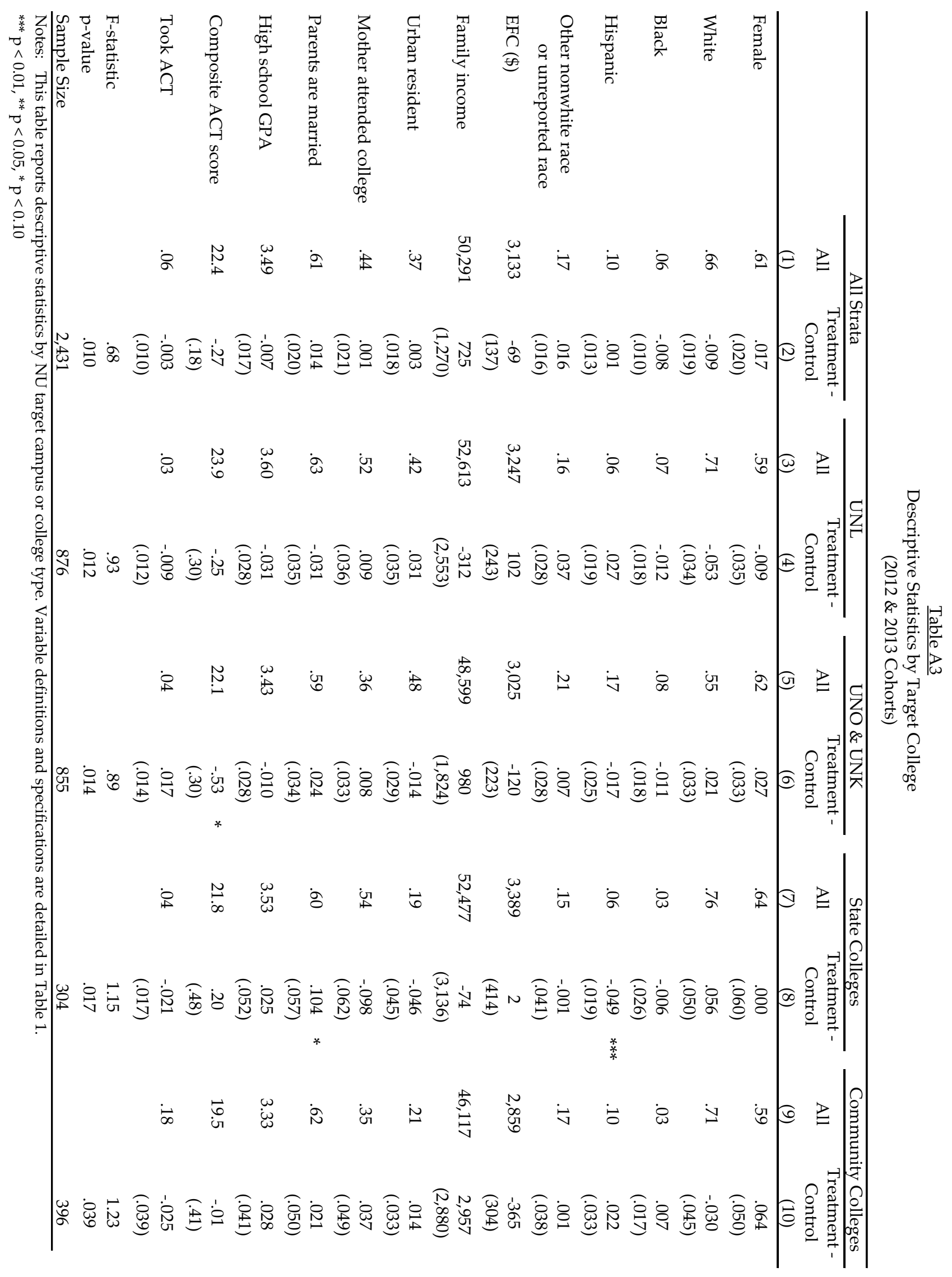


Table A4

First Stage Effect on Year One and Year Two Financial Aid Packages for Nebraska Public College Students

(2012 \& 2013 Cohorts)

\begin{tabular}{|c|c|c|c|c|c|c|c|c|c|c|}
\hline & \multicolumn{5}{|c|}{ Year One Aid Packages } & \multicolumn{5}{|c|}{ Year Two Aid Packages } \\
\hline & $\begin{array}{c}\text { Control } \\
\text { Mean } \\
(1)\end{array}$ & $\begin{array}{c}\text { Covariate } \\
\text { Adjusted } \\
(2)\end{array}$ & & $\begin{array}{c}\text { Campus } \\
\text { Adjusted } \\
(3)\end{array}$ & & $\begin{array}{c}\text { Control } \\
\text { Mean } \\
(4)\end{array}$ & $\begin{array}{c}\text { Covariate } \\
\text { Adjusted } \\
(5)\end{array}$ & & $\begin{array}{c}\text { Campus } \\
\text { Adjusted } \\
(6)\end{array}$ & \\
\hline Cost of attendance & 17,469 & $\begin{array}{r}1,129 \\
(196)\end{array}$ & $* * *$ & $\begin{array}{c}104 \\
(147)\end{array}$ & & 17,104 & $\begin{array}{r}1,650 \\
(388)\end{array}$ & $* * *$ & $\begin{array}{l}-30 \\
(277)\end{array}$ & \\
\hline Total aid & 11,608 & $\begin{array}{r}3,319 \\
(234)\end{array}$ & $* * *$ & $\begin{array}{r}2,168 \\
(202)\end{array}$ & $* * *$ & 8,957 & $\begin{array}{r}4,155 \\
(421)\end{array}$ & $* * *$ & $\begin{array}{r}2,619 \\
(379)\end{array}$ & $* * *$ \\
\hline Total grants & 7,251 & $\begin{array}{r}6,225 \\
(184)\end{array}$ & $* * *$ & $\begin{array}{c}5,467 \\
(167)\end{array}$ & $* * *$ & 5,233 & $\begin{array}{l}6,439 \\
(320)\end{array}$ & $* * *$ & $\begin{array}{l}5,341 \\
(294)\end{array}$ & $* * *$ \\
\hline Federal grants & 2,635 & $\begin{array}{l}25 \\
(67)\end{array}$ & & $\begin{array}{r}-135 \\
(63)\end{array}$ & $* *$ & 2,255 & $\begin{array}{c}58 \\
(131)\end{array}$ & & $\begin{array}{l}-173 \\
(130)\end{array}$ & \\
\hline Pell & 2,541 & $\begin{array}{l}42 \\
(64)\end{array}$ & & $\begin{array}{r}-109 \\
(61)\end{array}$ & * & 2,185 & $\begin{array}{c}74 \\
(127)\end{array}$ & & $\begin{array}{l}-141 \\
(125)\end{array}$ & \\
\hline Other federal grants & 94 & $\begin{array}{l}-18 \\
(10)\end{array}$ & * & $\begin{array}{l}-26 \\
(10)\end{array}$ & $* * *$ & 70 & $\begin{array}{l}-16 \\
(16)\end{array}$ & & $\begin{array}{l}-32 \\
(17)\end{array}$ & * \\
\hline State grants & 527 & $\begin{array}{l}-25 \\
(42)\end{array}$ & & $\begin{array}{l}-91 \\
(42)\end{array}$ & $* *$ & 335 & $\begin{array}{r}-118 \\
(52)\end{array}$ & $* *$ & $\begin{array}{r}-171 \\
(55)\end{array}$ & $* * *$ \\
\hline Institutional grants & 2,904 & $\begin{array}{l}-380 \\
(111)\end{array}$ & $* * *$ & $\begin{array}{l}-635 \\
(111)\end{array}$ & $* * *$ & 2,305 & $\begin{array}{l}-456 \\
(184)\end{array}$ & $* *$ & $\begin{array}{l}-803 \\
(191)\end{array}$ & $* * *$ \\
\hline STBF grant & 0 & $\begin{array}{c}6,924 \\
(77)\end{array}$ & $* * *$ & $\begin{array}{c}6,744 \\
(77)\end{array}$ & $* * *$ & 0 & $\begin{array}{r}7,034 \\
(144)\end{array}$ & $* * *$ & $\begin{array}{r}6,625 \\
(144)\end{array}$ & $* * *$ \\
\hline Other private grants & 1,185 & $\begin{array}{r}-318 \\
(80)\end{array}$ & $* * *$ & $\begin{array}{r}-417 \\
(84)\end{array}$ & $* * *$ & 338 & $\begin{array}{l}-80 \\
(75)\end{array}$ & & $\begin{array}{r}-138 \\
(82)\end{array}$ & * \\
\hline Total government loans & 3,529 & $\begin{array}{r}-2,220 \\
(148)\end{array}$ & $* * *$ & $\begin{array}{r}-2,524 \\
(153)\end{array}$ & $* * *$ & 3,239 & $\begin{array}{r}-1,674 \\
(257)\end{array}$ & $* * *$ & $\begin{array}{r}-2,025 \\
(274)\end{array}$ & $* * *$ \\
\hline Subsidized Stafford & 1,586 & $\begin{array}{c}-1,241 \\
(60)\end{array}$ & $* * *$ & $\begin{array}{c}-1,359 \\
(61)\end{array}$ & $* * *$ & 1,549 & $\begin{array}{r}-1,017 \\
(114)\end{array}$ & $* * *$ & $\begin{array}{r}-1,184 \\
(118)\end{array}$ & $* * *$ \\
\hline Unsubsidized Stafford & 907 & $\begin{array}{r}-166 \\
(66)\end{array}$ & ** & $\begin{array}{r}-252 \\
(66)\end{array}$ & $* * *$ & 866 & $\begin{array}{l}-55 \\
(111)\end{array}$ & & $\begin{array}{l}-118 \\
(115)\end{array}$ & \\
\hline Perkins & 308 & $\begin{array}{r}-246 \\
(21)\end{array}$ & $* * *$ & $\begin{array}{r}-276 \\
(23)\end{array}$ & $* * *$ & 158 & $\begin{array}{r}-117 \\
(29)\end{array}$ & $* * *$ & $\begin{array}{r}-147 \\
(32)\end{array}$ & $* * *$ \\
\hline PLUS & 728 & $\begin{array}{r}-566 \\
(80)\end{array}$ & $* * *$ & $\begin{array}{r}-637 \\
(86)\end{array}$ & $* * *$ & 666 & $\begin{array}{l}-485 \\
(135)\end{array}$ & $* * *$ & $\begin{array}{l}-575 \\
(153)\end{array}$ & $* * *$ \\
\hline Federal Work Study & 829 & $\begin{array}{r}-486 \\
(45)\end{array}$ & $* * *$ & $\begin{array}{r}-580 \\
(46)\end{array}$ & $* * *$ & 485 & $\begin{array}{r}-272 \\
(63)\end{array}$ & $* * *$ & $\begin{array}{r}-372 \\
(67)\end{array}$ & $* * *$ \\
\hline Campus controls & & No & & Yes & & & No & & Yes & \\
\hline Sample size & 1,093 & 1,928 & & 1,928 & & 365 & 777 & & 777 & \\
\hline
\end{tabular}

Notes: This table reports effects of the STBF scholarship offer on students' financial aid packages, showing results for detailed aid categories. Samples, specifications, and variable definitions are detailed in Tables 2 and 3.

${ }^{* * *} \mathrm{p}<0.01,{ }^{* *} \mathrm{p}<0.05,{ }^{*} \mathrm{p}<0.10$ 


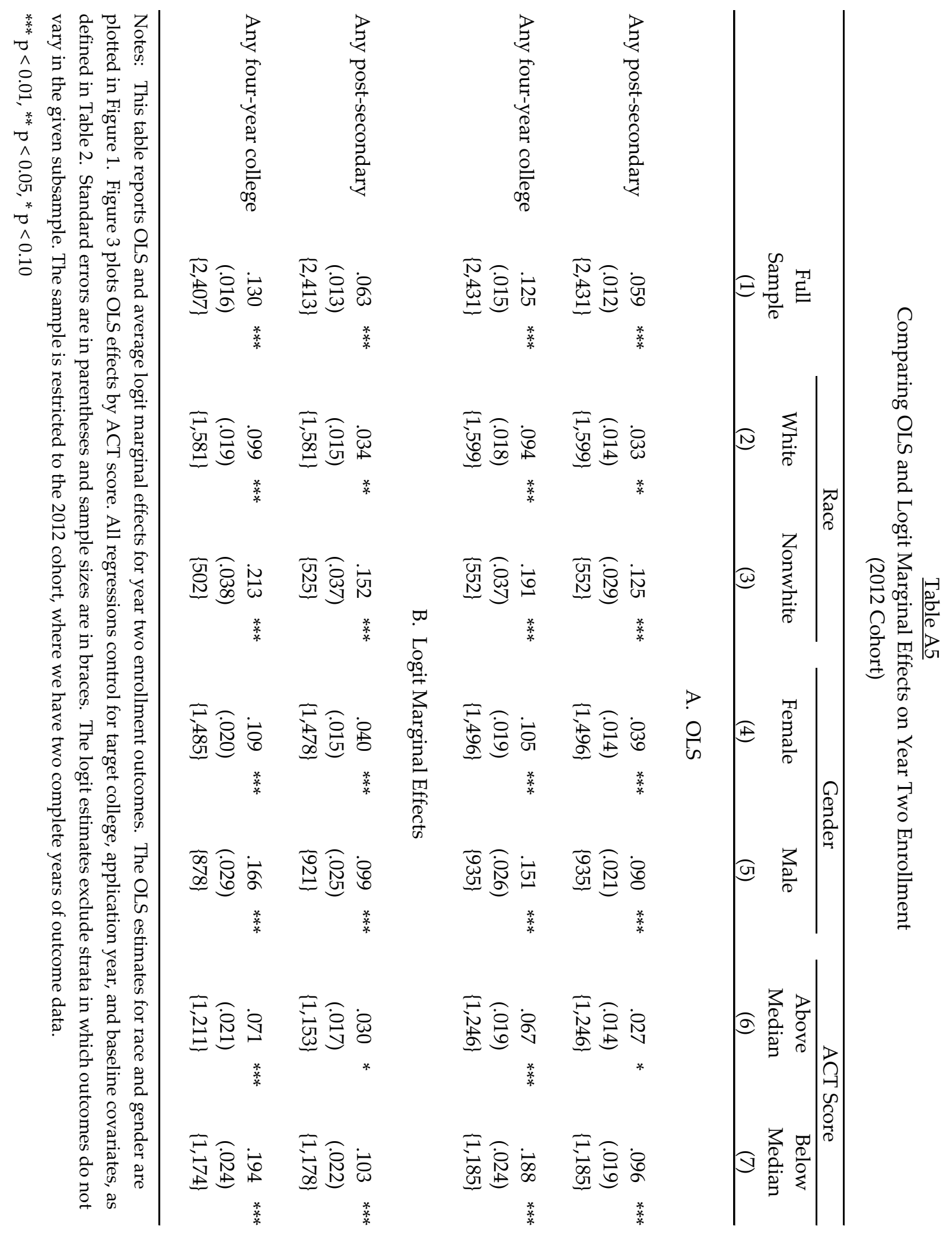


Figure 1: Effect on Year Two Enrollment by Subgroup
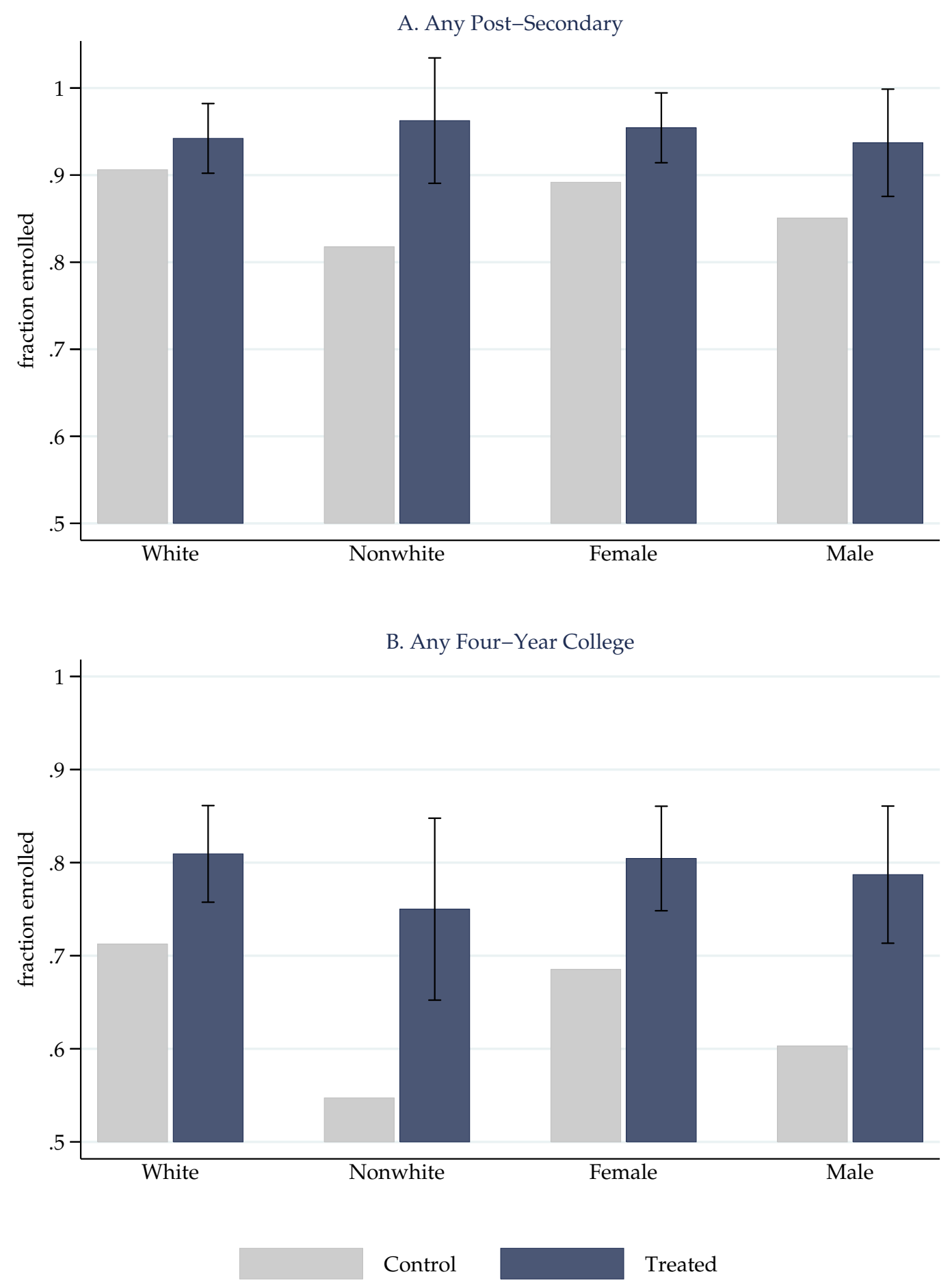

Notes: Results are for the 2012 full award sample. Treated bars plot the sum of the control mean and estimated treatment effect. Whiskers show 95 percent confidence intervals. 
Figure 2: Effect on Year Two Enrollment by GPA

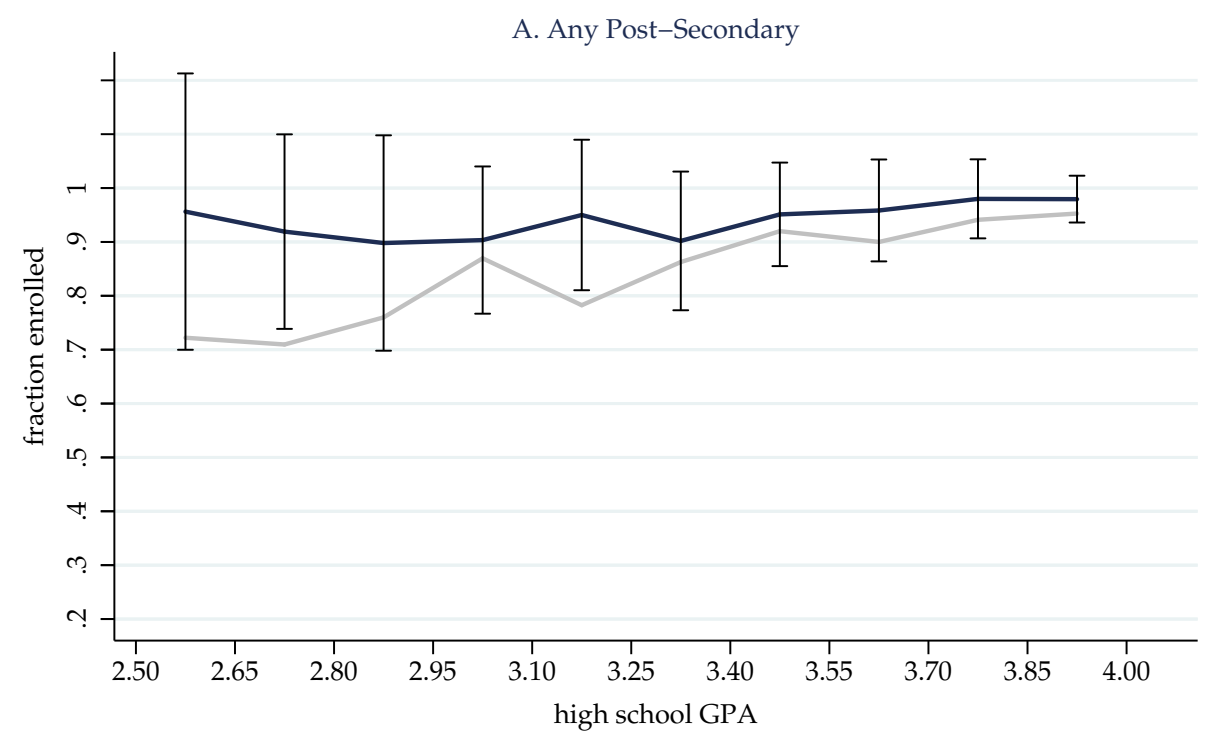

B. Any Four-Year College

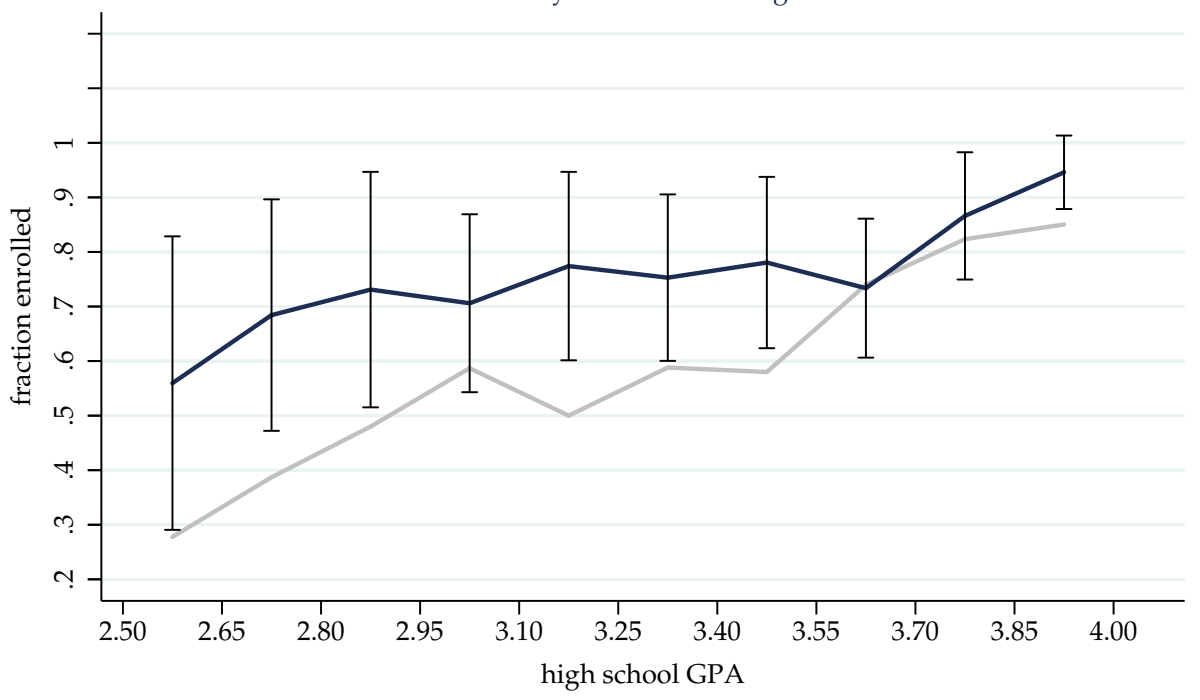

Control

Treated

Notes: Results are for the 2012 full award sample. Treated points plot the sum of the control mean and estimated treatment effect. Whiskers show 95 percent confidence intervals. 
Figure 3: Effect on Year Two Enrollment by ACT

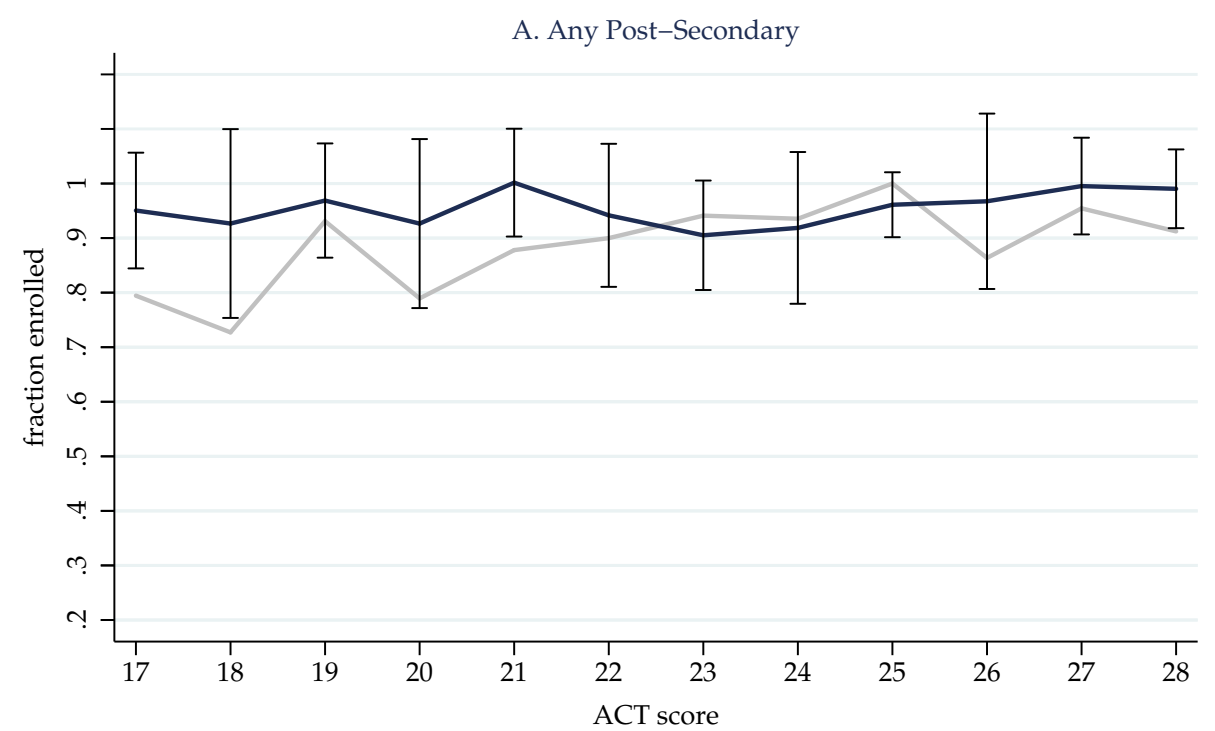

B. Any Four-Year College

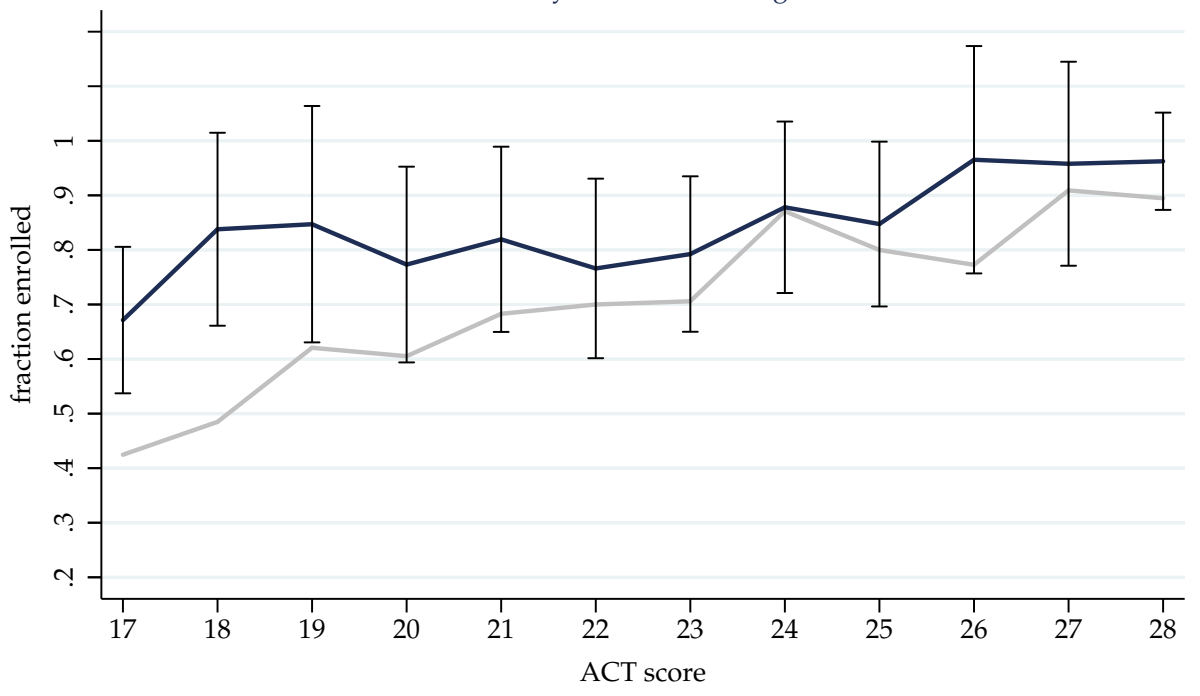

Control

Treated

Notes: Results are for the 2012 full award sample. Treated points plot the sum of the control mean and estimated treatment effect. Whiskers show 95 percent confidence intervals. The $\mathrm{x}$ axis ranges from 17 to 28 , the 10 th and 90 th percentiles of the score distribution among ACT test takers in the sample. 
Figure 4: Effect on Year Two Enrollment by EFC

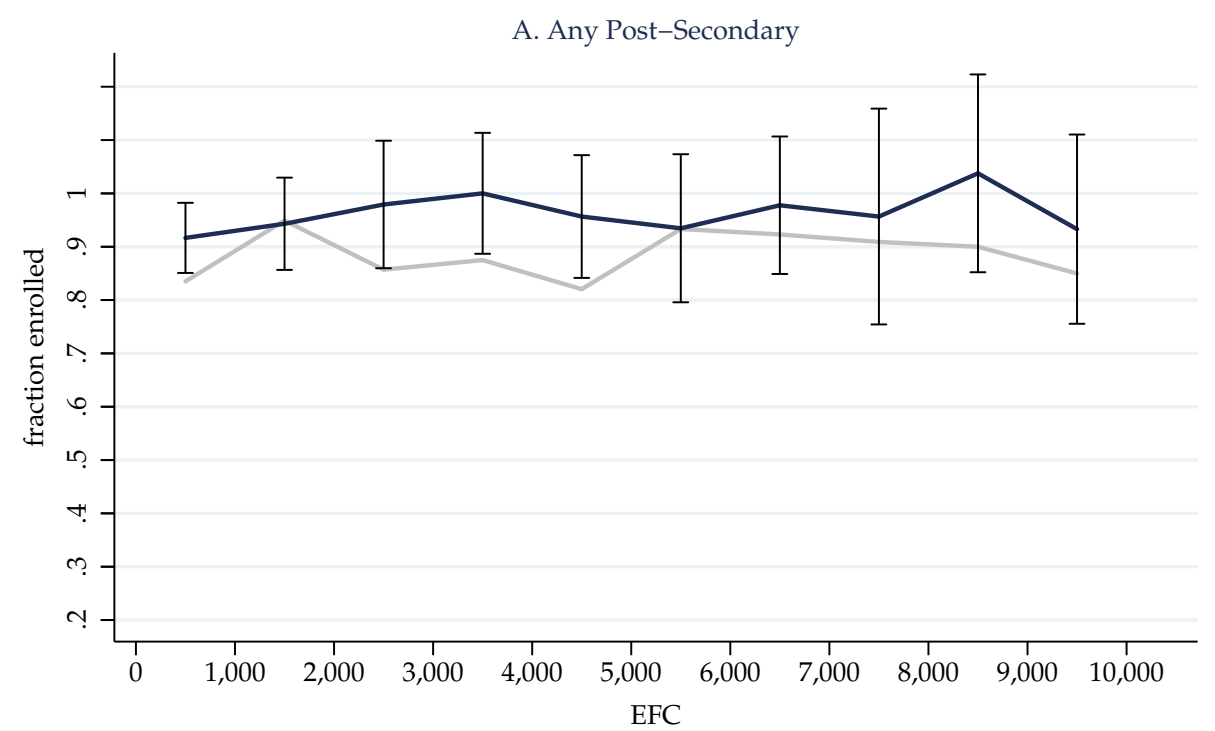

B. Any Four-Year College

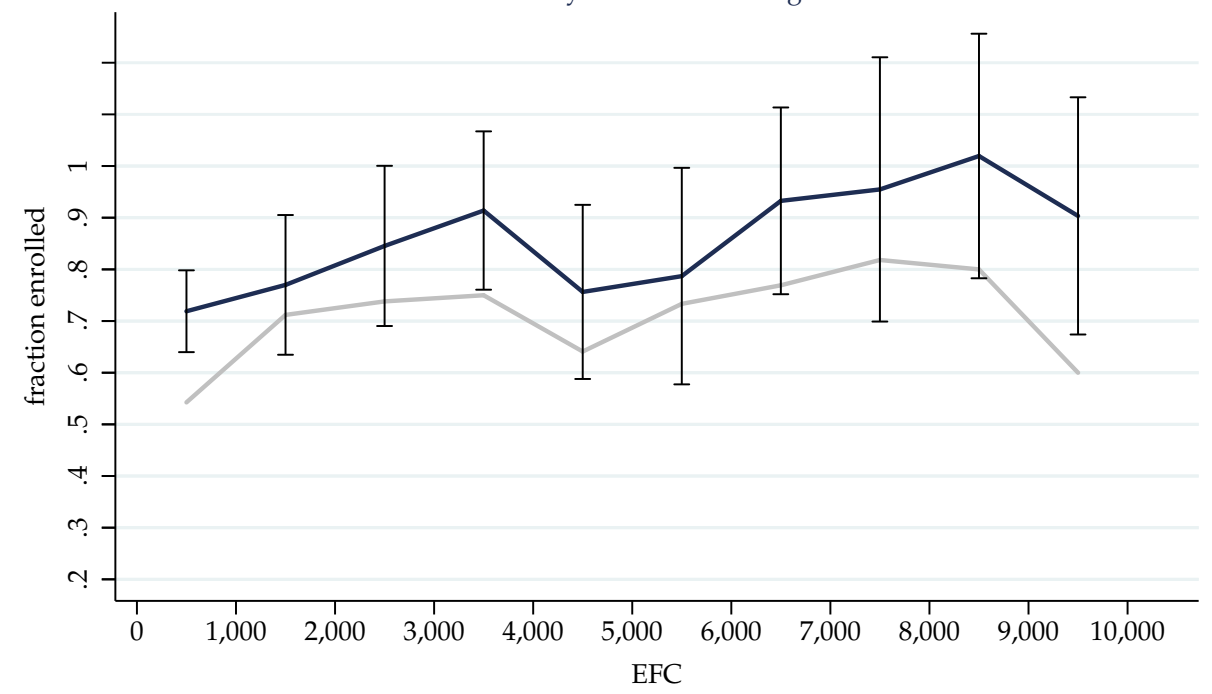

Control

Treated

Notes: Results are for the 2012 full award sample. Treated points plot the sum of the control mean and estimated treatment effect. Whiskers show 95 percent confidence intervals. 
Figure 5: Year Two Enrollment Effects Conditional on Estimated College Readiness
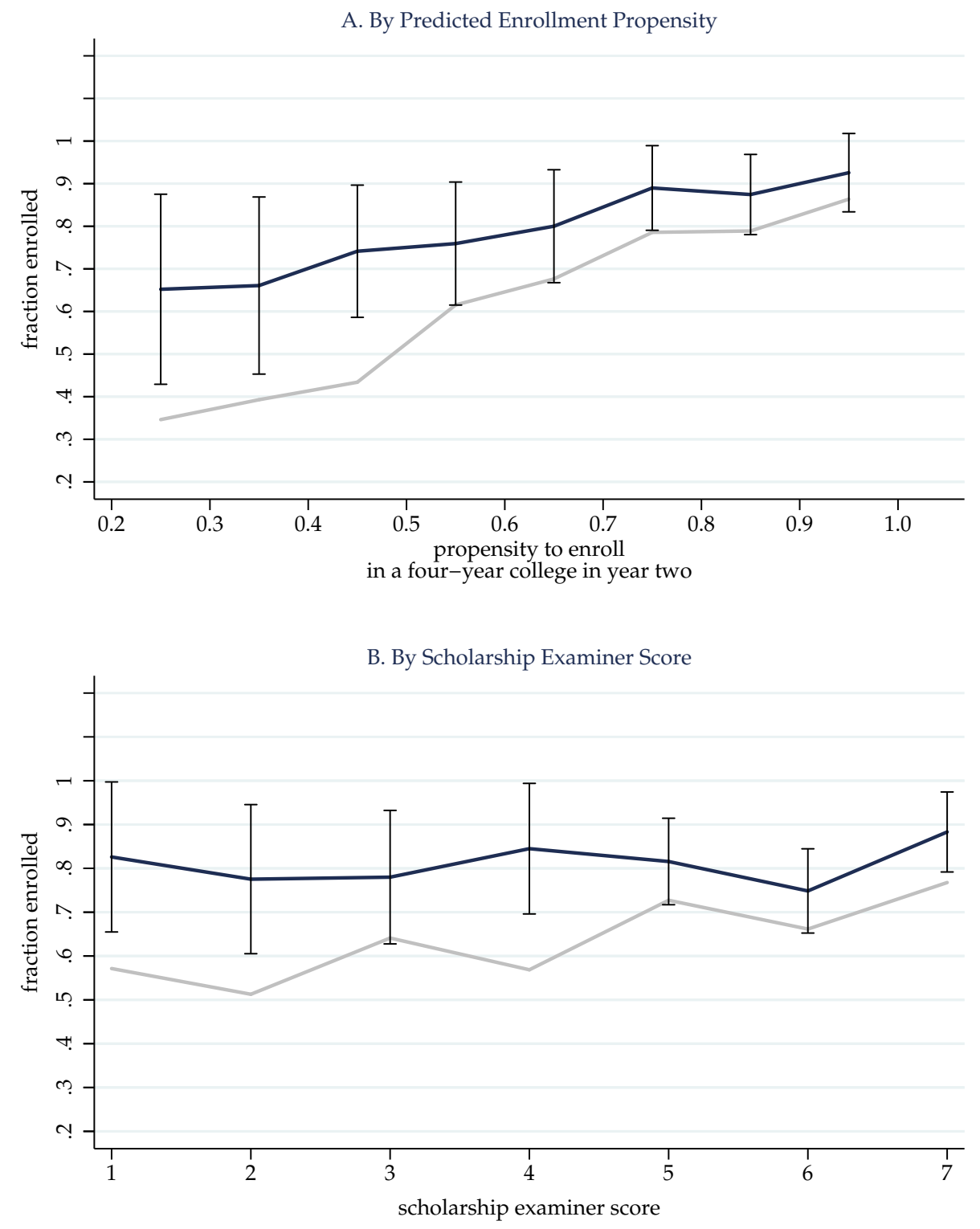

Control Treated

Notes: Results are for the 2012 full award sample. Treated points plot the sum of the control mean and estimated treatment effect. Whiskers show 95 percent confidence intervals. In panel $\mathrm{A}$, the $\mathrm{x}$ axis is propensity to enroll in a four-year college in year two, estimated using the leave-one-out procedure proposed by Abadie, Chingos and West (2013). 


\section{A Data Appendix}

This appendix describes our data sources and details the variables used in our analysis.

\section{A.1 Application Data}

The STBF scholarship application provides detailed data on applicants' baseline characteristics. The academic measures come primarily from high school transcripts, which report GPA and ACT scores. We standardize GPAs to a 4.0 scale using grade conversion formulae provided by the University of Nebraska-Lincoln. Since not all high schools report ACT scores on their transcripts, we supplement transcript data with self-reported scores from the application survey for 54 percent of the experimental sample. ${ }^{16}$

Most of our financial and demographic data come from applicants' Student Aid Reports (SARs). These reports are available for all STBF applicants who filed the Free Application for Federal Student Aid (FAFSA). SARs contain responses to more than 100 FAFSA questions regarding students' financial resources and family structure, including family income, parents' marital status, and parents' education. Roughly three percent of scholarship applicants are undocumented immigrants, who are ineligible for federal financial aid and therefore cannot file the FAFSA. STBF permits these students to submit an alternate form called the College Funding Estimator (CFE). The CFE is published by the EducationQuest Foundation, a non-profit organization in Nebraska, and offers a similar, though less detailed, set of information.

Neither SARs nor CFEs report students' race, and the scholarship application did not collect this variable until the 2014 cohort. For the 2012 and 2013 cohorts, we acquired these data from the Nebraska Department of Motor Vehicles. We matched more than 85 percent of the randomization sample to their state driver's license records.

\section{A.2 Enrollment Data}

More than 90 percent of experimental subjects enrolled in Nebraska public colleges, which provide administrative records for this research. We match applicants to these data using name, date of birth, and the last four digits of Social Security Numbers. To measure enrollment at out-of-state

\footnotetext{
${ }^{16}$ In Nebraska, the vast majority of students take the ACT rather than the SAT. For the 2012 cohort, 70 percent of Nebraska high school students took the ACT, compared to the national average of 52 percent.
} 
and private institutions, we match applicants to National Student Clearinghouse (NSC) data using name and date of birth. Though the NSC captures more than 91 percent of enrollment nationwide (and more than 99 percent at four-year public institutions), its name-based match has limitations, as Dynarski, Hemelt and Hyman (2015) detail. Roughly four percent of experimental applicants have enrollment at Nebraska public colleges that does not appear in our NSC-matched sample. These students are disproportionately nonwhite and, in particular, Hispanic.

Most of the enrollment outcomes reported in this paper are binary measures. Table 4, for example, reports effects on the probability of enrollment in year one. We define follow-up windows to match the federal financial aid year, which runs from July 1 to June 30. Year one begins on the July 1 following scholarship application and ends on the following June 30 (U.S. Department of Education 2012).Within each window, we force binary enrollment outcomes to be mutually exclusive. Students who enroll at both two- and four-year institutions are coded as "any four-year". Likewise, those who enroll at in-state public colleges do not contribute to the out-of-state or private categories, and selectivity outcomes are defined by the most selective institution attended.

We also report cumulative enrollment outcomes in Tables 5 and 7 . The ideal measure would be total semester credits enrolled, but not all schools use semester calendars and we don't observe credits for the seven percent of applicants who attend out-of-state or private colleges. For these schools, we impute credits per term from the NSC's coarse enrollment status variable, which indicates whether students were enrolled full-time, half-time, or less than half-time. Imputed credits is the mean of credits taken by Nebraska public college students with the same enrollment status, college attended, and academic term. Less than $2 \%$ of applicants attend out-of-state or private schools that do not report the full-time enrollment indicator to the NSC. We code these students as enrolled full-time if IPEDS reports that over $85 \%$ of the students attending in the same college are full-time. Once we have imputed credits per term for each enrollment period, we convert all credits to semester credit equivalents using the conversion factors outlined in the Federal Student Aid Handbook. Credits from colleges with quarter-based calendars, for instance, are worth twothirds of a semester credit because there are three quarters and two semesters in the academic year, excluding summer. Finally, we convert semester credit equivalents to full-time semester equivalents by dividing by 12 , the minimum credit hour requirement for full-time enrollment status. In these units, a student who enrolls for two semesters each year and 15 credits per semester will accumulate 
five full-time semester equivalents by the end of year two.

\section{A.3 Financial Aid Data}

Nebraska's public colleges also provide detailed information on their students' financial aid packages, which we analyze in Tables 2, 3, and A4. These data report costs of attendance, grants, loans, and Federal Work Study aid. While all schools report federal loans, most do not report private loans, which may be obtained directly from lenders without involving financial aid officers. We therefore exclude private loans from our analysis. For most students in our sample, however, federal loans offer the lowest available interest rate and therefore account for the vast majority of borrowing. 